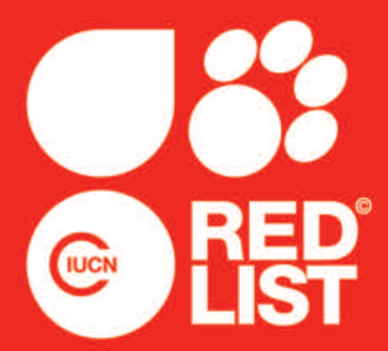

\title{
THE STATUS AND DISTRIBUTION OF MEDITERRANEAN BUTTERFLIES
}

Catherine Numa, Chris van Swaay, Irma Wynhoff, Martin Wiemers, Violeta Barrios, David Allen, Catherine Sayer, Miguel López Munguira, Emilio Balletto, Dubi Benyamini, Stoyan Beshkov, Simona Bonelli, Robert Caruana, Leonardo Dapporto, Filip Franeta, Patricia Garcia-Pereira, Evrim Karaçetin, Ahmad Katbeh-Bader, Dirk Maes, Nikola Micevski, Rebecca Miller, Eva Monteiro, Riadh Moulai, Ana Nieto, Lazaros Pamperis, Guy Pe'er, Andrew Power, Martina Šašić, Katy Thompson, Elli Tzirkalli, Rudi Verovnik, Martin Warren and Hilary Welch

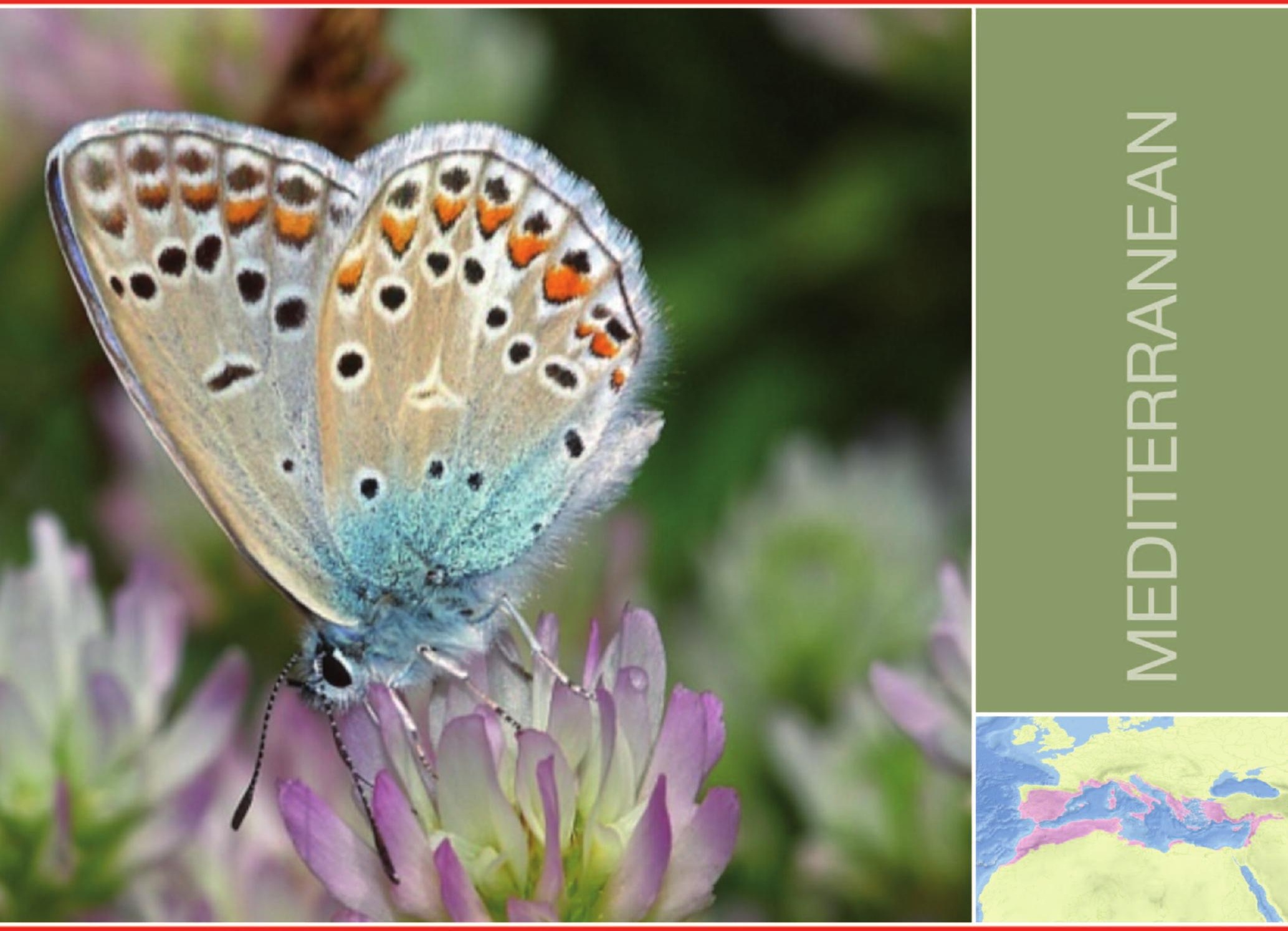

The IUCN Red List of Threatened Species ${ }^{\mathrm{TM}}$ - Regional Assessment 


\section{About IUCN}

IUCN is a membership Union composed of both government and civil society organisations. It harnesses the experience, resources and reach of its 1,300 Member organisations and the input of some 15,000 experts. IUCN is the global authority on the status of the natural world and the measures needed to safeguard it.

\section{www.iucn.org}

https://twitter.com/IUCN/

\section{IUCN - The Species Survival Commission}

The Species Survival Commission (SSC) is the largest of IUCN's six volunteer commissions with a global membership of more than 10,000 experts. SSC advises IUCN and its members on the wide range of technical and scientific aspects of species conservation and is dedicated to securing a future for biodiversity. SSC has significant input into the international agreements dealing with biodiversity conservation.

\section{http://www.iucn.org/theme/species/about/species-survival-commission-ssc}

\section{IUCN - Global Species Programme}

The IUCN Species Programme supports the activities of the IUCN Species Survival Commission and individual Specialist Groups, as well as implementing global species conservation initiatives. It is an integral part of the IUCN Secretariat and is managed from IUCN's international headquarters in Gland, Switzerland. The Species Programme includes a number of technical units covering Species Trade and Use, the IUCN Red List Unit, Freshwater Biodiversity Unit (all located in Cambridge, UK), the Global Biodiversity Assessment Initiative (located in Washington DC, USA), and the Marine Biodiversity Unit (located in Norfolk, Virginia, USA).

\section{www.iucn.org/species}

\section{IUCN - Centre for Mediterranean Cooperation}

The Centre was opened in October 2001 with the core support of the Spanish Ministry of Agriculture, Fisheries and Environment the regional Government of Junta de Andalucía and the Spanish Agency for International Development Cooperation (AECID). IUCN has over 203 members in the Mediterranean region, including 15 governments. Its mission is to influence, encourage, and assist Mediterranean societies to conserve and use sustainably the natural resources of the region and work with IUCN members and cooperate with all other agencies that share the objectives of the IUCN.

\section{www.iucn.org/mediterranean}




\section{THE STATUS AND DISTRIBUTION OF MEDITERRANEAN BUTTERFLIES}

Catherine Numa, Chris van Swaay, Irma Wynhoff, Martin Wiemers, Violeta Barrios, David Allen, Catherine Sayer, Miguel López Munguira, Emilio Balletto, Dubi Benyamini, Stoyan Beshkov, Simona Bonelli, Robert Caruana, Leonardo Dapporto, Filip Franeta, Patricia Garcia-Pereira, Evrim Karaçetin, Ahmad Katbeh-Bader, Dirk Maes, Nikola Micevski, Rebecca Miller, Eva Monteiro, Riadh Moulai, Ana Nieto, Lazaros Pamperis, Guy Pe'er, Andrew Power, Martina Šašić, Katy Thompson, Elli Tzirkalli, Rudi Verovnik, Martin Warren and Hilary Welch 


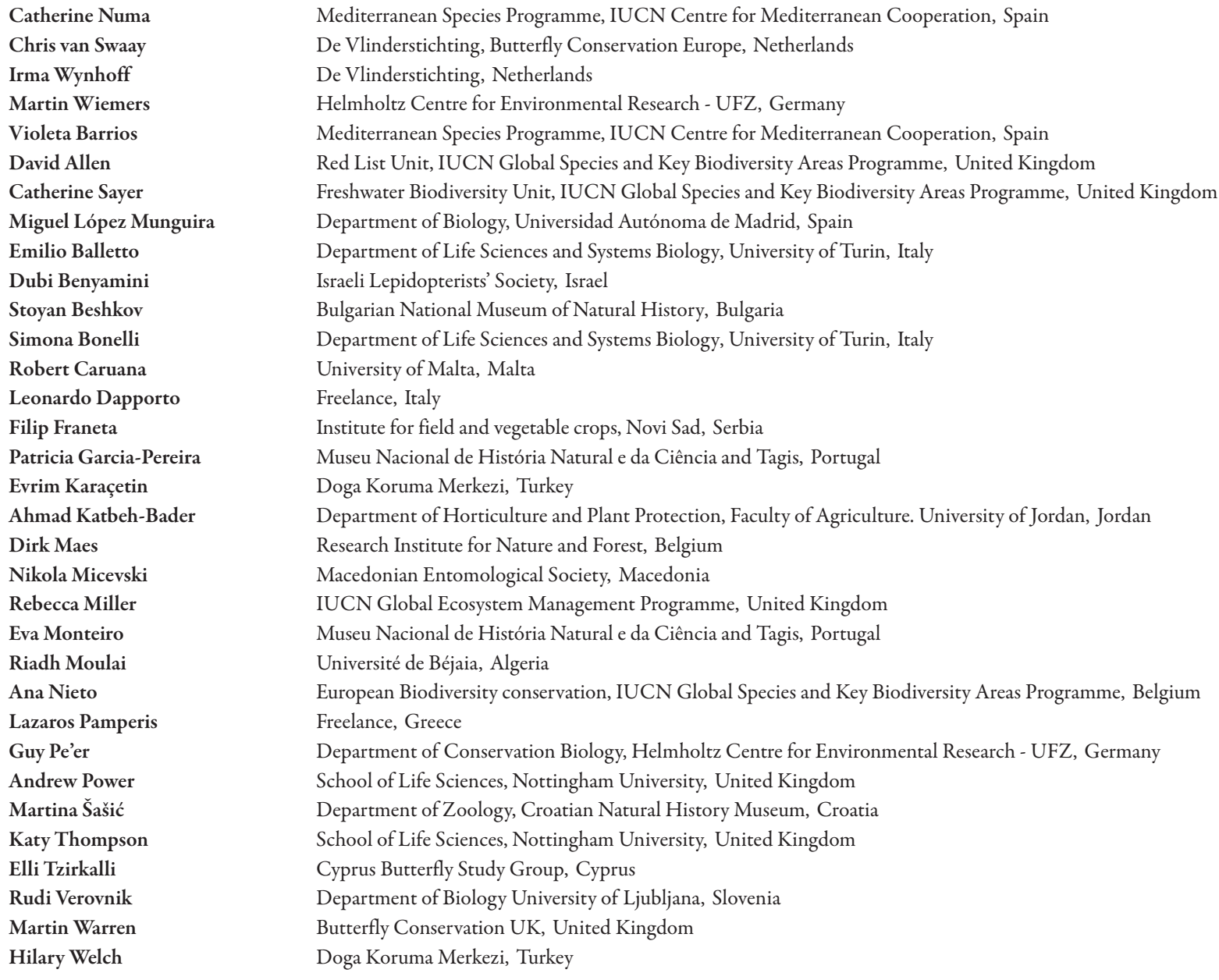

The designation of geographical entities in this report and the presentation of the material do not imply the expression of any opinion whatsoever on the part of IUCN or other participating organizations concerning the legal status of any country, territory, or area, or its authorities, or concerning the delimitation of its frontiers or boundaries.

The views expressed in this publication do not necessarily reflect those of IUCN or other participating organizations.

Published by:

Copyright:

\section{Red List logo:}

Citation:

ISBN:

DOI:

Cover photo:

Layout by:

Printed by:

Available from:
IUCN, Malaga, Spain

(C) 2016 International Union for Conservation of Nature and Natural Resources

Reproduction of this publication for educational or other non-commercial purposes is authorized without prior written permission from the copyright holder provided the source is fully acknowledged.

Reproduction of this publication for resale or other commercial purposes is prohibited without prior written permission of the copyright holder.

\section{(C) 2008}

Numa, C., van Swaay, C., Wynhoff, I., Wiemers, M., Barrios, V., Allen, D., Sayer, C., López Munguira, M., Balletto, E., Benyamini, D., Beshkov, S., Bonelli, S., Caruana, R., Dapporto, L., Franeta, F., Garcia-Pereira, Karaçetin, E., Katbeh-Bader, A., Maes, D., Micevski, N., Miller, R., Monteiro, E., Moulai, R., Nieto, A., Pamperis, L., Pe'er, G., Power, A., Šašić, M., Thompson, K., Tzirkalli, E., Verovnik, R., Warren, M. and Welch, H. (2016). The status and distribution of Mediterranean butterflies. IUCN, Malaga, Spain. $\mathrm{x}+32 \mathrm{pp}$.

978-2-8317-1790-6

http://dx.doi.org/10.2305/IUCN.CH.2016.MRA.6.en

The Bolland's Blue (Polyommatus bollandi) only occurs in Hatay (Turkey) and is considered Critically Endangered. It is threatened by urbanization, quarrying and overgrazing. (C)Ali Atahan

Simétrica, S. L.

Solprint S. L.

IUCN Centre for Mediterranean Cooperation

C/ Marie Curie 22

29590 Campanillas, Malaga, Spain.

Tel: +34952028430 - Fax: +34952028145

http://www.iucn.org/mediterranean

http://www.iucn.org/resources/publications

The text of this book is printed on 115 gsm environmentally-friendly paper. 


\section{Table of contents}

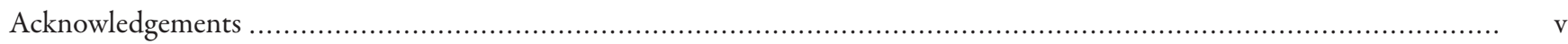

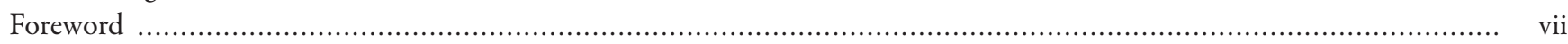

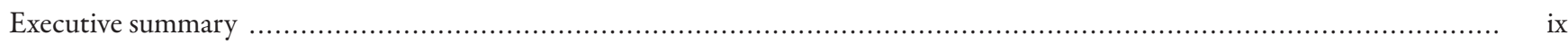

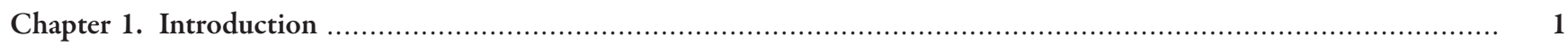

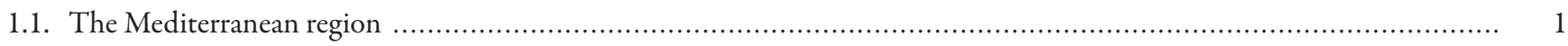

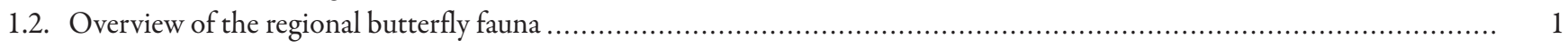

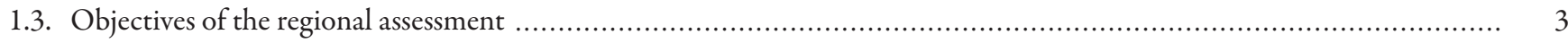

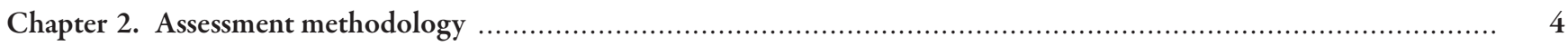

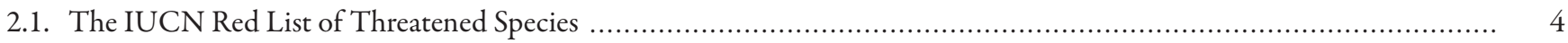

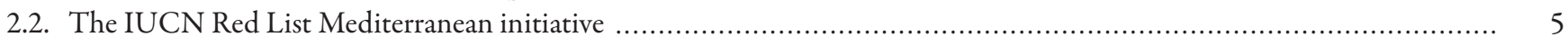

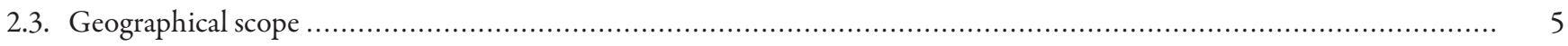

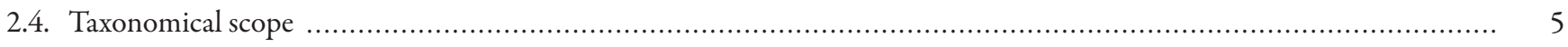

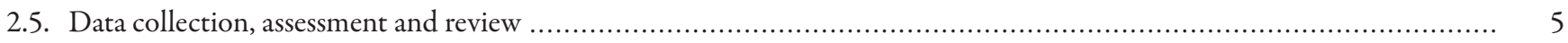

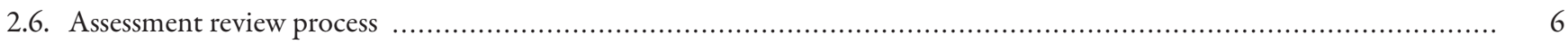

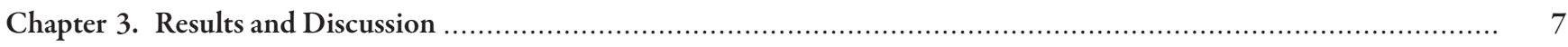

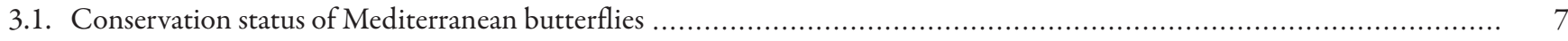

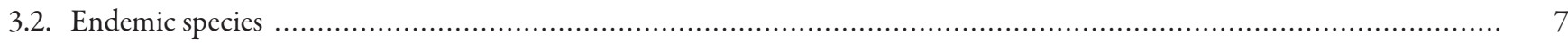

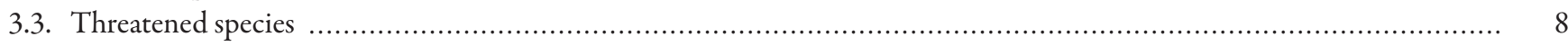

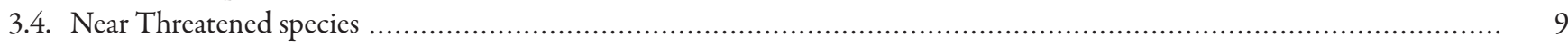

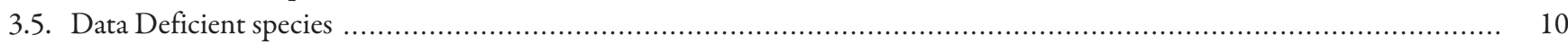

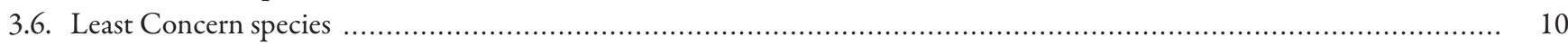

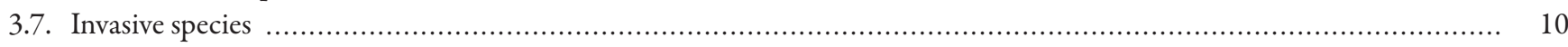

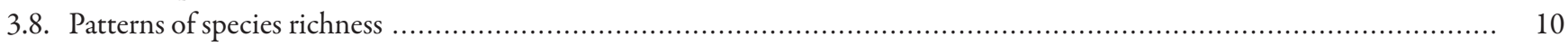

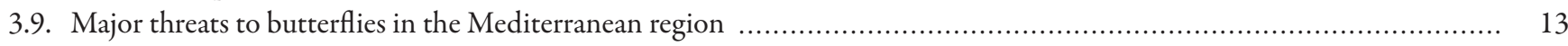

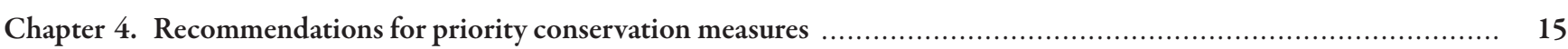

4.1. International and regional instruments relevant to the conservation and management of Mediterranean butterflies ......... 15

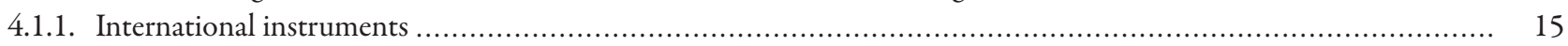

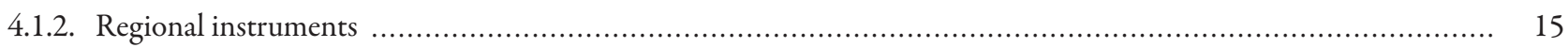

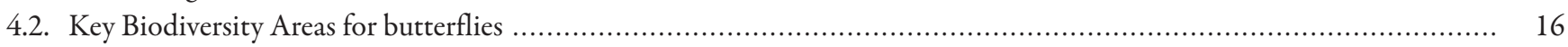

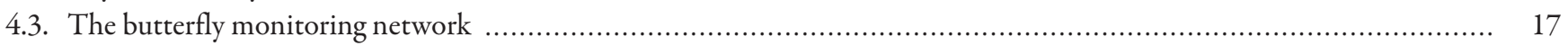

4.4. Strategic planning for Mediterranean species conservation: action plans for butterfly species in Sierra Nevada, Spain ........ 17

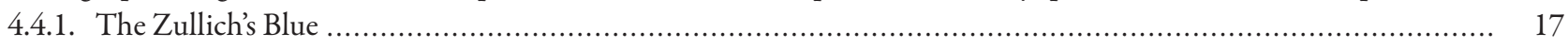

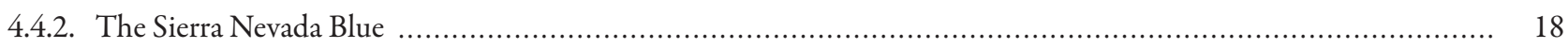

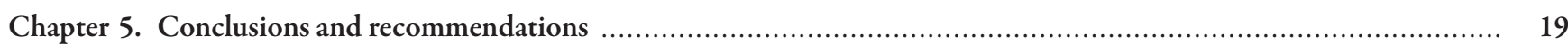

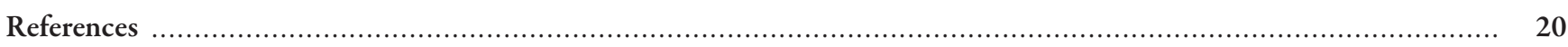

Appendix 1. Summary of regional IUCN Red List status of all Mediterranean butterfly species assessed ........................ 21

\section{List of Figures}

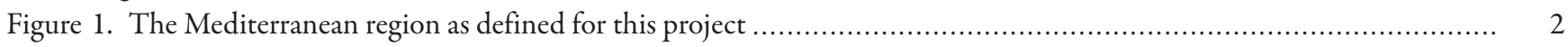

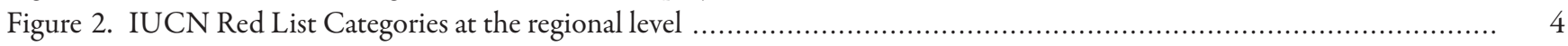

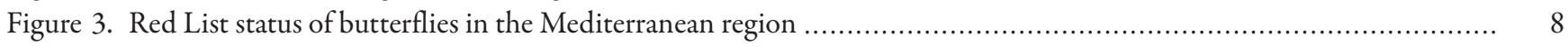

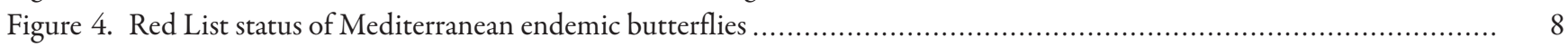

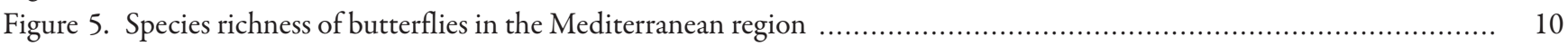


Figure 6. Species richness of endemic butterflies in the Mediterranean region

Figure 7. Distribution of threatened butterflies in the Mediterranean region

Figure 8. Summary of threats to all native species assessed in the Mediterranean region

\section{List of tables}

Table 1. Diversity and endemism in butterfly families in the Mediterranean region

Table 2. Summary of the Red List status of butterflies in the Mediterranean region

Table 3. Butterfly species listed as threatened at the Mediterranean regional level ...

Table 4. Proportion of threatened species in the Mediterranean region

Table 5. Legal protection of butterflies at international and regional level in the Mediterranean 


\section{Acknowledgements}

Assessing species for the IUCN Red List of Threatened Species relies on the willingness of dedicated experts to contribute and pool their collective knowledge to make the most reliable estimates of the conservation status of species. Without their enthusiastic commitment to species conservation, this work would not be possible. Additionally, we would like to thank the Patronato Botánico Municipal ‘Ciudad de Málaga’ for providing the excellent facilities for the review workshop.

Jean-Christophe Vié, Craig Hilton-Taylor and Caroline Pollock provided guidance, support and good advice throughout the project. Ackbar Jolia, Jemma Able and Elisa Alcázar provided valuable support on GIS and database issues. Lourdes Lázaro, Natalie Lobartolo and Arantxa Cendoya also provided valuable support during the different stages of the project. Mohamed Karmass provided assistance with financial management of the project.

We specially thank Scott Hoffman Black (IUCN Butterfly Red List Authority) for their support and for their thorough review of the species assessments in the very short deadline given.
We would like to thank José Miguel Barea, Javier Olivares, Rudi Verovnik and Ali Atahan for providing the photographs and Cristina Novo for commenting and proofreading this document.

Species data were provided by many experts throughout the Mediterranean; we would therefore like to express our sincere thanks to all of the Mediterranean butterfly experts who provided information for the assessments which were completed at the Malaga workshop in February 2013, especially to Louis Cassar, Christian Darcemont, Pascal Dupont, Francis Gilbert, Eddie John, Ernestino Maravalhas, Branko Micevski, Ozge Ozden, Michel Tarrier and Wolfgang ten Hagen. The work presented in this report was supported by the IUCN Centre for Mediterranean Cooperation and the IUCN Species Programme (Red List Unit). This project was funded by the MAVA Foundation with the contribution of the Spanish Ministry of Environment and Junta de Andalucia.

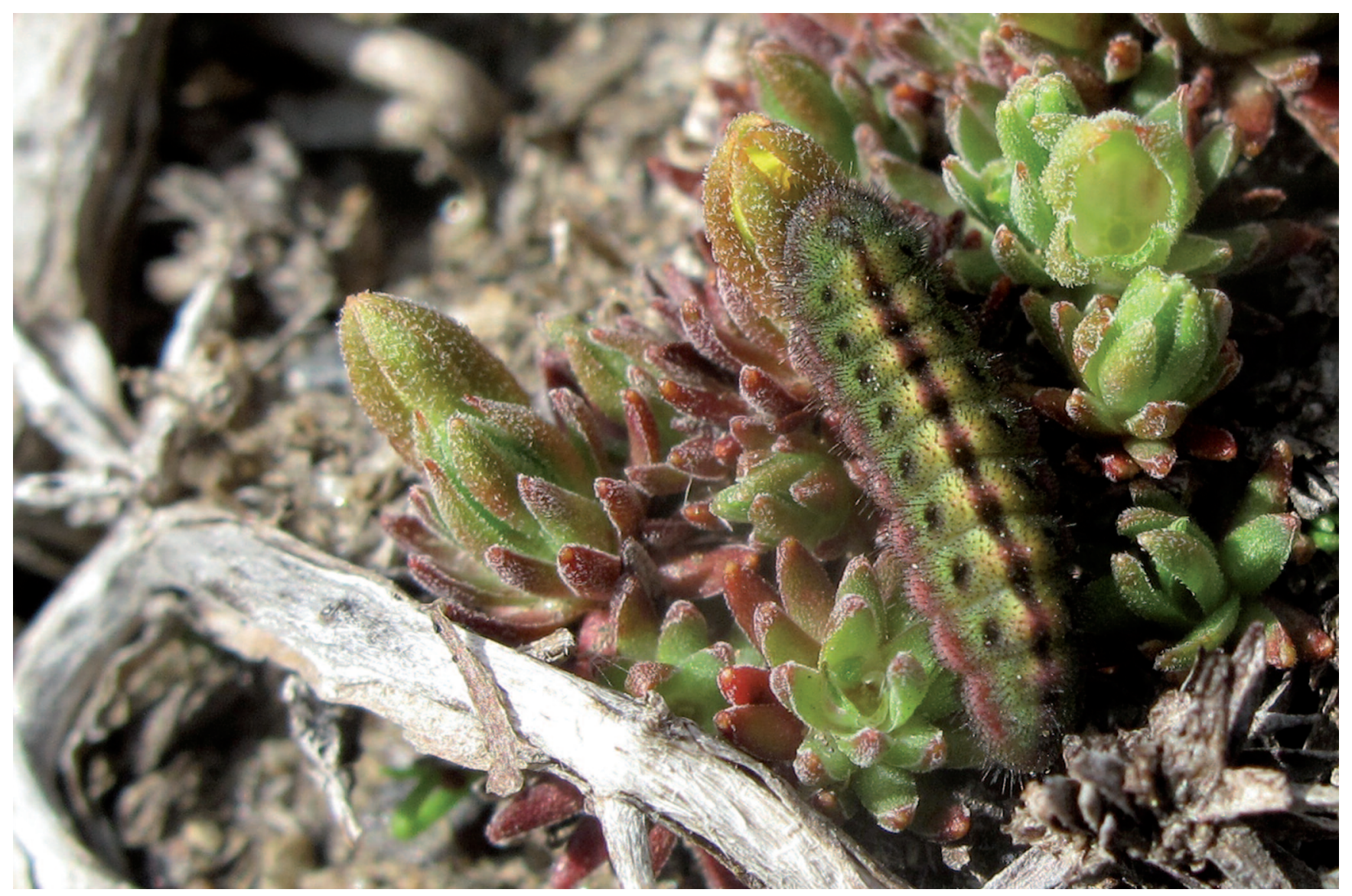

Larva of Zullich’s Blue (Plebejus zullichi) on its food plant Androsace vitaliana. (c) José Miguel Barea. 



\section{Foreword}

The Mediterranean basin is home to many animals and plants that are found nowhere else on Earth. It is also recognized as a Global Biodiversity Hotspot, an area that besides being extremely rich in biodiversity is also under threat.

People have lived in the Mediterranean for thousands of years, and have turned it into a mosaic of natural and cultural landscapes. However, in recent decades the region has been put under tremendous pressure due to the growing human population. As a result of coastal development, the overexploitation of natural resources and changing climatic conditions, biodiversity is now highly threatened by habitat loss and degradation. Unsurprisingly, the Mediterranean basin is one of the four most significantly altered biodiversity hotspots in the world.

In a changing environment, it is critical to understand how wild plants and animals are faring, what the main threats affecting their populations are, and which conservation measures are in place, or should be implemented, to minimize their extinction risk. Assessing the conservation status of species at the Mediterranean level is particularly important to guide and inform regional policy instruments. The IUCN Red List of Threatened Species is also an important way to monitor progress towards achieving the new global Sustainable Development Goals, in particular numbers 14 and 15 which seek to halt marine and terrestrial biodiversity loss.

The Mediterranean Red List is a regional initiative focused on assessing the extinction risk of species in the Mediterranean basin. It is in the Mediterranean region that, 10 years ago, IUCN developed its first regional Red List with the support of Fondation MAVA, a successful model that was later replicated in other regions. Several groups have already been comprehensively assessed, namely mammals, reptiles, birds, freshwater fishes, cartilaginous fishes, crabs and crayfish, and dragonflies.
Butterflies are a charismatic and very visible group of species, a group of indicator species that was missing. The Status and Distribution of Mediterranean Butterflies is the latest addition to the already impressive number of species assessed at this regional level. Adding another invertebrate group also makes an important contribution towards making the Mediterranean Red List more representative of the overall Mediterranean biodiversity.

There are 463 recorded butterfly species within the Mediterranean region, of which 98 are endemic. This publication reveals that almost $5 \%$ of the species assessed are threatened with extinction, and that $79 \%$ of those threatened species are endemic. The main threat to butterflies is habitat loss due to the changes in the management of semi-natural grasslands either through intensification, overgrazing or abandonment.

However, for more than $6 \%$ of the species there was not enough available information to assess their extinction risk, and these species were classified as Data Deficient. Regional cooperation among Mediterranean countries is urgently needed in order to improve the knowledge on the status of all butterfly species, and to minimize their extinction risk throughout the Mediterranean basin.

I hope this publication will serve as a source of sound scientific data to decision-makers for policy development and management of natural resources, and that it will provide a basis for future conservation work on Mediterranean butterflies. In addition, I hope it will inspire people to learn more about, and care for, these remarkable creatures.

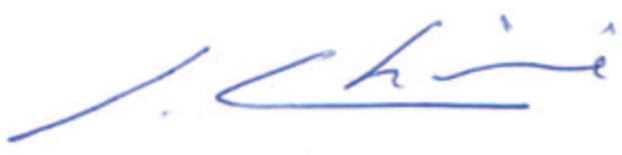

Jean-Christophe Vié

Deputy Director, IUCN Global Species Programme Director, SOS - Save Our Species Partnership 


\section{Foreword}

The Mediterranean is a region rich in natural and cultural heritage, characterized by high levels of species diversity and endemism. It is the second largest of the 34 biodiversity hotspots in the world. It stretches across more than 22 countries, including major terrestrial habitats such as forests, maquis, garrigue, pasture, wetlands, coastal areas and areas of transition (ecotones) between each of these and desert zones.

IUCN, as a global organisation, is the leading provider of biodiversity knowledge, tools and standards used to influence policy, undertake conservation planning and guide action on the ground. Knowledge is key and the IUCN Centre for Mediterranean Cooperation (IUCN-Med) works to leverage its knowledge, standards and tools to influence policy and to support action in the Mediterranean region, particularly those undertaken by IUCN Members. Better knowledge about biodiversity, including threats and conservation measures, will help drive action. By combining credible knowledge, standards and tools with a mobilized network of members and partners, real change in policies and action on the ground to conserve biodiversity is possible.

In that context, Regional Mediterranean Red Lists are an important tool to scientifically assess and communicate the status of species. They provide comprehensive information about the situation of biodiversity in the region and are an important practical mechanism for implementing national and regional strategies for biodiversity conservation of the Convention for Biological Diversity.

Mediterranean Red Listing contributes directly to Aichi Targets, in particular Target 12, which calls for the prevention and improvement of the conservation status of known threatened species by 2020. The assessments of the Mediterranean Red Lists are carried out in partnership with organizations and individuals around the region, and will help to deliver these various targets.
The current Mediterranean landscape and the remarkable natural richness of the hotspot is a consequence of the intense interaction that took place over millennia. Although bringing higher diversity, this modification has also placed great pressure on wildlife and natural areas. For example, more than $50 \%$ of wetlands were reported to have disappeared over the past century, and their decline and deterioration continue. Local species depletions have mostly occurred among large species, including marine mammals, birds, turtles, commercial fish and invertebrates.

Butterflies are key organisms for Mediterranean ecosystems functioning through pollination and as prey for other species. This report presents a review of the conservation status of 462 species of butterflies native to the Mediterranean biodiversity hotspot undertaken by experts from around the region. Since its establishment in 2001, the primary role of the IUCN Med has been to assess the regional conservation status of selected taxonomic groups. The Red List of Butterflies is the ninth publication in the series.

The assessment shows us that at least 19 butterfly species are threatened with extinction in the region. Unfortunately, the drivers for these declines are still in place. The conversion of grasslands into agricultural land for arable farming or forestry, unsustainable levels of grazing as well as livestock abandonment are important threats to Mediterranean butterflies.

This Red List for Mediterranean butterflies adds another piece of evidence to the fact that efforts to halt the loss of biodiversity in the region need a major boost in the coming years to safeguard our natural capital for future generations.

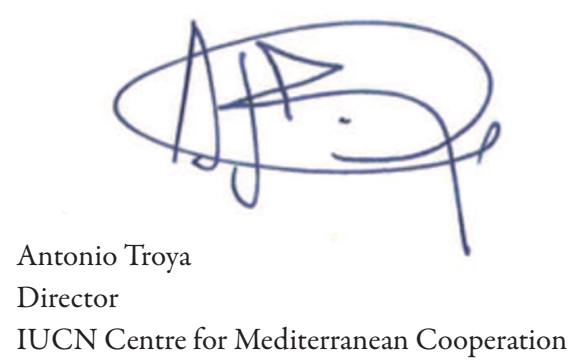




\section{Executive summary}

\section{Aim}

The Mediterranean Red List assessment is a review of the conservation status at regional level of approximately 6,000 species (amphibians, mammals, reptiles, fishes, butterflies, dragonflies, beetles, molluscs, corals and plants) according to the IUCN Red List Categories and Criteria. It identifies those species that are threatened with extinction at the regional level to guide appropriate conservation actions for improving their status. This report summarises the results for Mediterranean butterflies.

\section{Scope}

The geographical scope is the Mediterranean region according to the Mediterranean Basin Biodiversity Hotspot (Mittermeier et al. 2004), with exception of the Macaronesian islands which have not been included in this study.

\section{Conservation status assessment}

The species conservation status was assessed using the IUCN Red List Categories and Criteria (IUCN 2012a). The assessments followed the guidelines for application of IUCN Red List Criteria at regional levels (IUCN 2012b). They were compiled from a network of 35 experts from 20 countries in the region, and reviewed during a workshop in Málaga (Spain) in 2013 and through correspondence with relevant experts. All individual taxon assessments are available on the IUCN Red List website: http://www.iucnredlist.org/initiatives/mediterranean

\section{Mediterranean butterflies}

In the Mediterranean region 463 species of butterflies are recorded, 98 of them endemic (which means that they are unique to the Mediterranean and found nowhere else in the world). Thirty-four species occur only marginally in the region, while one species (Cacyreus marshalli) was introduced in the 1980s; and therefore these 35 were considered as Not Applicable in this assessment. The highest diversity of butterflies is found in mountainous areas in southern Turkey, northern Greece and southern France.

\section{Results}

Overall, about 5\% (19 species) of butterflies are threatened in the Mediterranean region. Two per cent are considered Near Threatened and more than $6 \%$ are Data Deficient. This

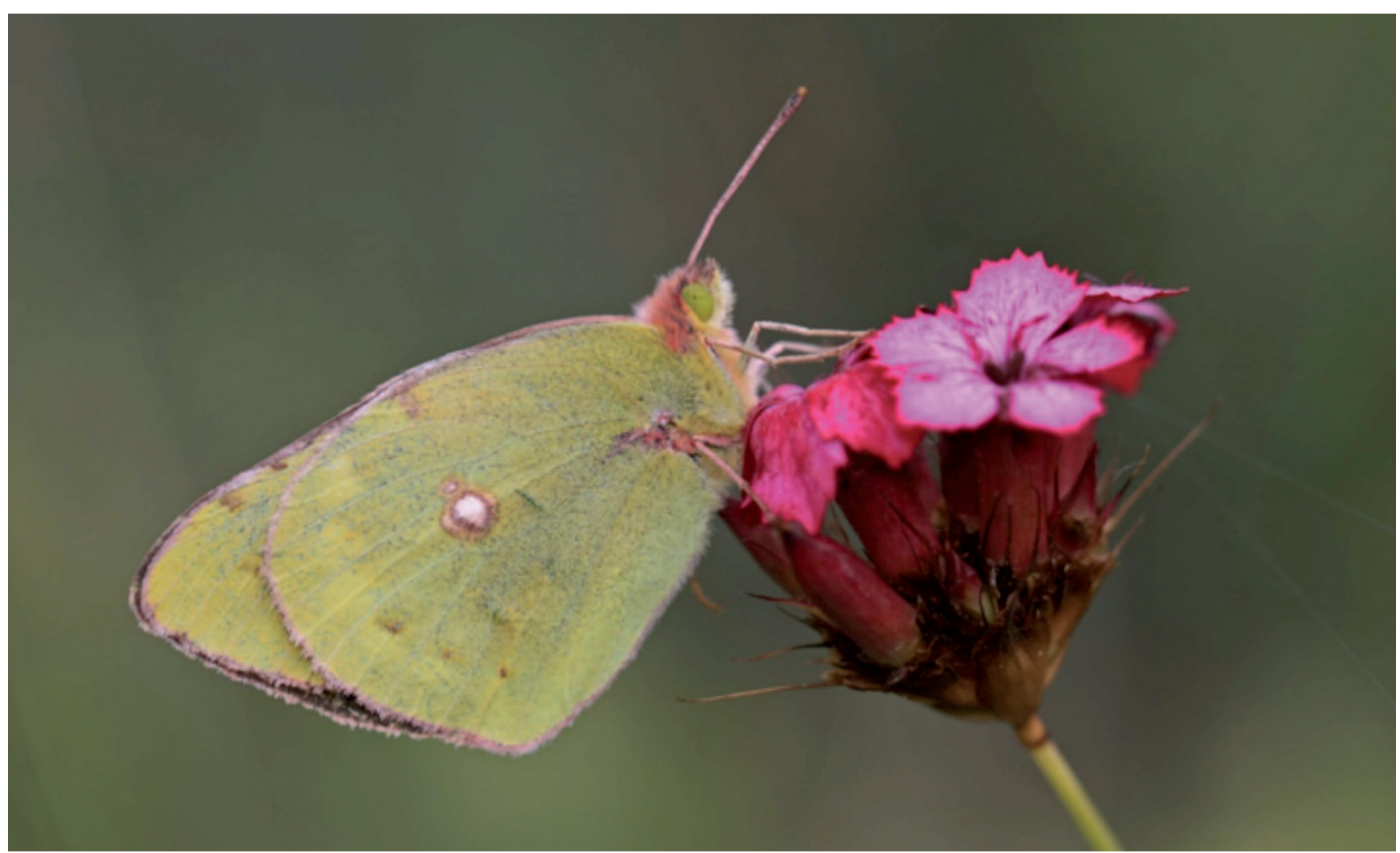

The Balkan Clouded Yellow (Colias caucasica) is classified as Endangered. It is a species restricted to Greece, where strong declines are reported because of changes in the grazing regime. (c) Rudi Verovnik. 
percentage is similar to those of Mediterranean birds and it is lower than for other groups assessed in the region such as amphibians (31\%), reptiles (13\%), mammals (14\%) and dragonflies (19\%). In the Mediterranean butterflies are slightly less threatened than in Europe (8\%), probably because of the higher area of remaining natural and semi-natural habitats throughout the region.

Almost $80 \%$ of the species threatened with extinction are endemic. Most of the threatened species are confined to high elevations in southern Spain, the High and MiddleAtlas in Morocco and the Anti-Taurus Mountains in southern Turkey.

The main current threat to Mediterranean butterflies is habitat loss due to the changes in the management of semi-natural grasslands either through intensification, overgrazing or abandonment. Other important threats are the intensity of tourism development in high mountains, specimen collection, domestic and agricultural pollution, climate change, transportation and service corridors, and mining.

In many Mediterranean countries there is a significant lack of information regarding distribution, population size and trends, especially in the southern and eastern part of the region.

\section{Conclusions and recommendations}

Although the percentage of threatened butterflies is lower than in other groups assessed in the region, there is an important lack of information regarding distribution, population size and trends for several species, which could result in an increased number of threatened species.

Changes in agricultural uses due to agricultural intensification, overgrazing and abandonment are a threat to Mediterranean butterfly diversity. Further conservation actions are necessary to improve its status:

- National and international legislation should be fully implemented and revised to include the threatened species identified in this assessment.

- Prioritize field work and data collection for Data Deficient species to determine whether they need conservation actions.

- Species/habitat action plans should be drawn for the most threatened species.

- Butterfly monitoring should be started up in many more parts of the Mediterranean. Only regular counts provide data to follow populations of butterflies in detail.

- Ensure that the strong regional cooperation between experts continues, and start new cooperation efforts with experts from countries where information is scarce, so that the work carried out to produce the first evaluation of the conservation status of native Mediterranean butterflies can be updated as new information becomes available. 


\section{Chapter 1. Introduction}

1.1. The Mediterranean region

1.2. Overview of the regional butterfly fauna .....

1.3. Objectives of the regional assessment

In February 2013, the IUCN Centre for Mediterranean Cooperation, in collaboration with the IUCN Species Programme and Butterfly Conservation (BC), established a regional group of experts to complete an overview of the regional conservation status of butterflies in the Mediterranean region.

This report presents a summary of the overall results of the assessments for all Mediterranean butterflies, highlighting species of greatest conservation concern as well as listing those of lesser concern. It is envisaged that the information contained within this report will help facilitate the development of priority research, conservation and management actions for the region.

\subsection{The Mediterranean region}

The Mediterranean basin stretches approximately 3,800 km from the tip of Portugal in the west to the shores of Lebanon in the east, and approximately $1,000 \mathrm{~km}$ from Italy in the north to Morocco and Libya in the south. It includes 24 countries spread across three continents. Environmental conditions in the Mediterranean region have a profound influence on the vegetation and wildlife of the area. The climate is characterised by hot dry summers and humid, cool winters, and the topography is varied and contrasting. The Mediterranean region offers a changing landscape of high mountains, rocky shores, scrubland, semi-arid steppes, coastal wetlands, sandy beaches and a myriad of islands of various shapes and sizes. The landscape is a direct result of centuries of human-induced activities such as forest fires, clearances, livestock grazing and cultivation (Sundseth 2009). These conditions have a profound influence on the vegetation and wildlife of the region, which constitutes one of the world's richest places in terms of animal and plant diversity, with a high level of endemism (Myers et al. 2000).

Currently home to around 465 million people, the Mediterranean region is also visited by an additional 360 million tourists every year. Population growth and tourism has not only caused the loss of wildlife-rich habitats by increasing urbanization and tourism infrastructure, but has also contributed further to chronic water shortages and has also had a major socio-economic impact on large parts of the region, as many small-scale farmers have been forced to abandon their land to go and search for jobs elsewhere. The last 50 years have seen a massive change in agricultural practices across the Mediterranean. Ancient vineyards, orchards and olive groves have been cleared to make way for industrial scale fruit or olive plantations, and mixed rotational farming has been replaced by intensive monocultures (Sundseth 2009).

Modern farming practices also put an inordinate amount of pressure on the surrounding environment through their high demand for pesticides, fertilisers and water irrigation. More than 26 million ha of farmland are now under irrigation in the Mediterranean basin and in some areas up to $80 \%$ of the available water is used for irrigation, which is leading to a severe overexploitation of both ground and surface waters (Sundseth 2009).

Human population growth, changes in traditional land uses (e.g. agriculture intensification and agricultural abandonment), overgrazing, invasion of non-native species, fires and tourism infrastructures are some of the major threats to Mediterranean biodiversity.

\subsection{Overview of the regional butterfly fauna}

Butterflies are a large group of insects, belonging to the order 'Lepidoptera', which means 'scaly wing'. They are characterized by their large, often colourful wings and by their proboscis, which they use to suck flower nectar. They lay eggs that hatch into larvae (called caterpillars), which have a totally different appearance from the adult, with a cylindrical body, and feed mainly on plant leaves, before going through metamorphosis to form a chrysalis. The butterflies (Papilionoidea) is a superfamily of Lepidoptera forming a small fraction of Mediterranean Lepidoptera, which also includes many species of moths (Heterocera).

This report only analyses the conservation status of butterflies (Papilionoidea). Many butterflies are valued for their beauty, but they also have an economic interest and play an important role in ecosystems through pollination and as prey for other species. They support a wide range of parasitoids, many of which are specific to their host and worthy of conservation in their own right. Butterflies are considered good indicators for the state of the environment and due to their short cycle, narrow niches and relatively low mobility, they are more sensitive to land-use changes than long-lived animals such as birds and mammals (Thomas and Clarke 2004). 


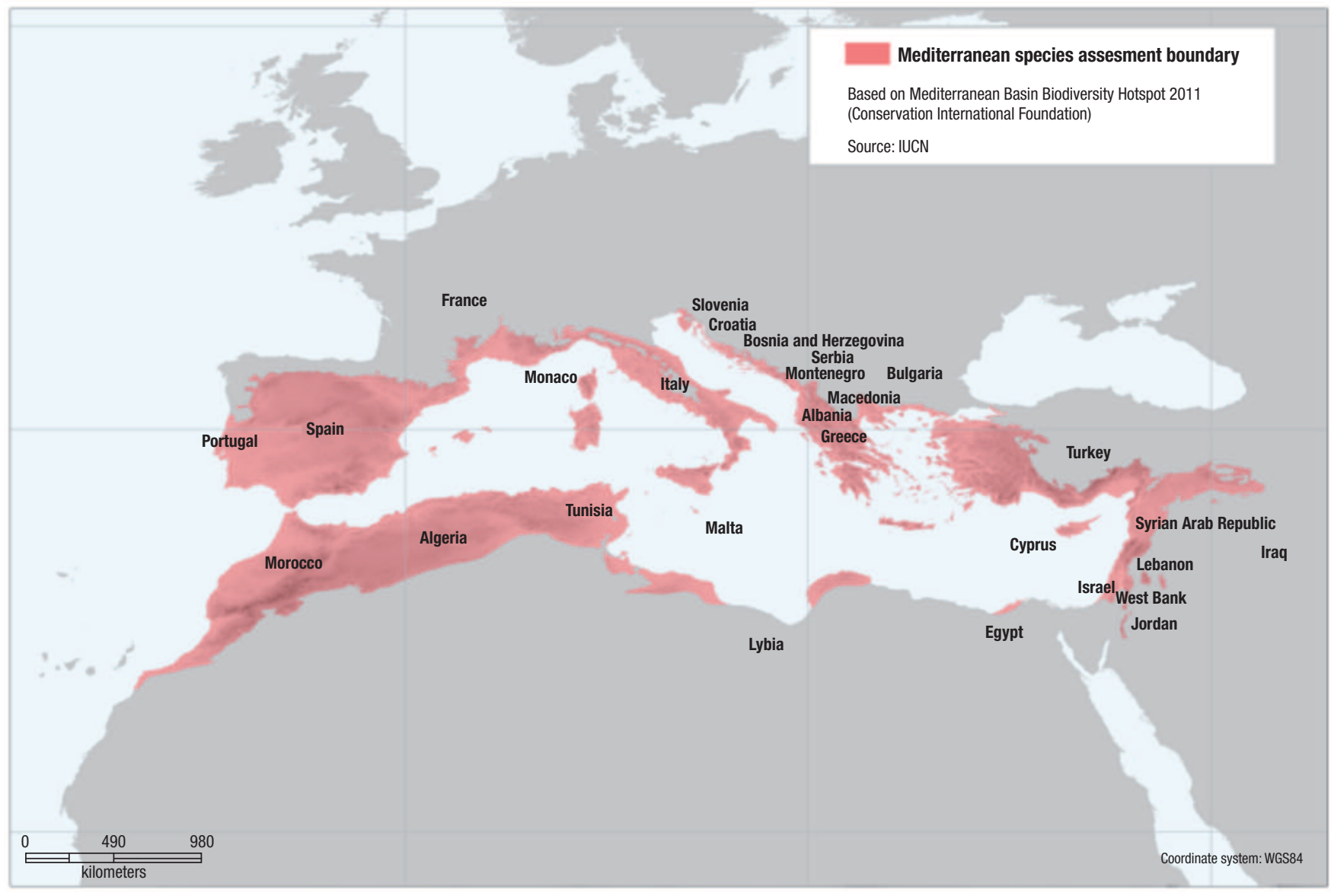

Figure 1. The Mediterranean region as defined for this project

In the Mediterranean, there are 462 native butterfly species divided into six families (Table 1). The two largest families are the Nymphalidae, with are often large and brightly-coloured species, such as the fritillaries, admirals, emperors, and tortoiseshells, also including the subfamily Satyrinae (browns); and the Lycaenidae, including the blues, the coppers and the hairstreaks, generally small brightly coloured butterflies, sometimes with a metallic gloss. The Riodinidae family, whose members are mainly distributed in the Neotropical region, is only represented with one species: Hamearis lucina, the Duke of Burgundy Butterfly, which is similar to the fritillaries, although this family Riodinidae is closely related to the Lycaenidae. Cacyreus marshalli, a South African species that was introduced in the Balearic Islands in 1989 (Eitschberger and Stamer 1990), is rapidly spreading across the Mediterranean; it is not a native species and therefore is not considered in this assessment and classed as Not Applicable (NA).

Table 1. Diversity and endemism in butterfly families in the Mediterranean region*

\begin{tabular}{|c|c|c|c|c|c|}
\hline Class & Order & Family & Number of species & Number of endemic species & $\%$ of endemic species \\
\hline \multirow[t]{6}{*}{ Insecta } & \multirow[t]{6}{*}{ Lepidoptera } & Hesperiidae & 52 & 7 & 13 \\
\hline & & Lycaenidae & 158 & 38 & 24 \\
\hline & & Nymphalidae & 188 & 44 & 24 \\
\hline & & Papilionidae & 14 & 2 & 14 \\
\hline & & Pieridae & 50 & 6 & 12 \\
\hline & & Riodinidae & 1 & 0 & 0 \\
\hline Total & & & 463 & 98 & 21 \\
\hline
\end{tabular}

* This table includes species that are native or were naturalised before AD 1500. Species of marginal occurrence or introduced in the Mediterranean region are also included. 
More than one fifth $(21 \%)$ of Mediterranean butterflies are endemic, that is, they occur only in this region. The families with the highest rates of endemism are the Nymphalidae and the Lycaenidae. The other families have a lower rate of endemism (12-14\%), and the only representative of the Riodinidae is not endemic to the Mediterranean region.

\subsection{Objectives of the regional assessment}

The Mediterranean regional assessment has three main objectives:

- To contribute to regional conservation planning by providing a baseline dataset describing the conservation status of Mediterranean butterflies.

- To identify geographic areas which need conservation measures to prevent extinctions and ensure that Mediterranean butterflies reach and maintain a favourable conservation status.
- To develop a network of regional experts to enable species assessments to be continually updated as new information is discovered and to provide expert opinion on policy and management recommendations.

The main outputs presented in this report are:

- a comprehensive species list of all Mediterranean butterflies;

- an IUCN Red List categorization of each species;

- a summary of the main threats affecting Mediterranean butterflies;

- recommendations for the future conservation of Mediterranean butterflies and their habitats.

The data presented in this report provides a snapshot based on the knowledge available at the time of the assessment. The database will continue to be updated and made freely available. IUCN will facilitate wide dissemination of this document to concerned decision makers, scientists and non-governmental organizations to mobilize Mediterranean native butterfly conservation action at the local, national and regional levels.

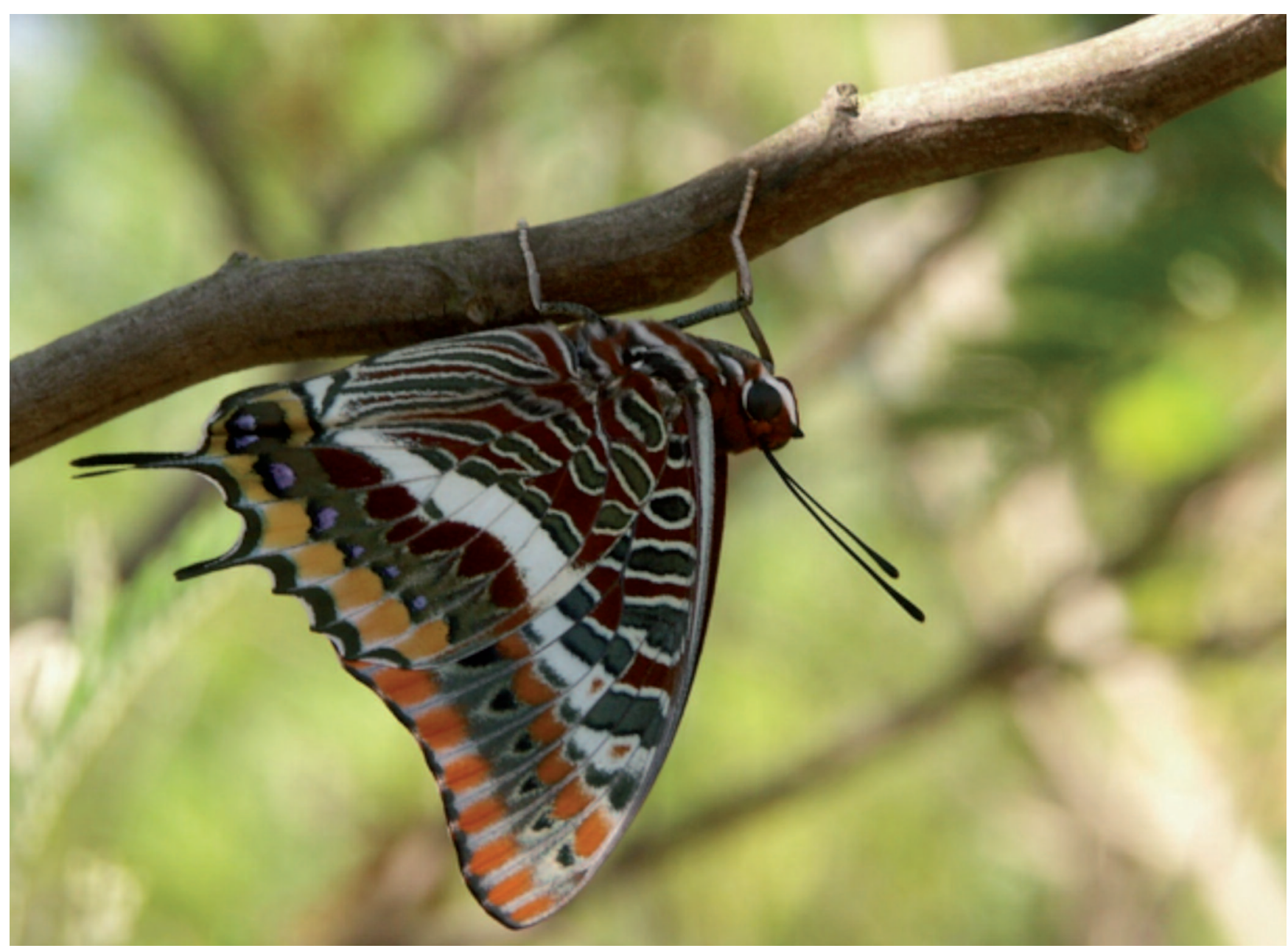

The Two-tailed Pasha (Charaxes jasius): although widespread, this species is local and restricted to (semi-) natural areas, and populations are decreasing in the Mediterranean. (c) Chris van Swaay. 


\section{Chapter 2. Assessment methodology}

2.1. The IUCN Red List of Threatened Species

2.2. The IUCN Red List Mediterranean initiative

2.3. Geographical scope

2.4. Taxonomical scope

2.5. Data collection, assessment and review

\subsection{The IUCN Red List of Threatened Species}

The IUCN Red List of Threatened Species ${ }^{\mathrm{TM}}$ (IUCN Red List) is widely recognized as the most comprehensive, scientificallybased source of information on the global conservation status of plant and animal species. IUCN Red List Categories and Criteria are applied to individual taxon assessments (which contain information on aspects such as ecology and life history, distribution, habitat, threats, current population trends and conservation measures), to determine their relative threat of extinction. Threatened species are listed as Critically Endangered (CR), Endangered (EN) or Vulnerable (VU). Taxa that are either close to meeting the threatened thresholds, or would be threatened were it not for ongoing conservation programmes, are classified as Near Threatened (NT). Taxa evaluated as having a relatively low risk of extinction are classified as Least Concern (LC). Also highlighted within the IUCN Red List are taxa that cannot be evaluated due to insufficient knowledge, and which have therefore been assessed as Data Deficient (DD). This category does not necessarily mean that the species is not threatened, only that its risk of extinction cannot be assessed from current data (IUCN 2009).

Additionally, when conducting regional or national assessments, the IUCN Red List Regional Guidelines (IUCN 2012b) are applied, and two additional categories are used: Regionally Extinct (RE) and Not Applicable (NA) (see Figure 2).

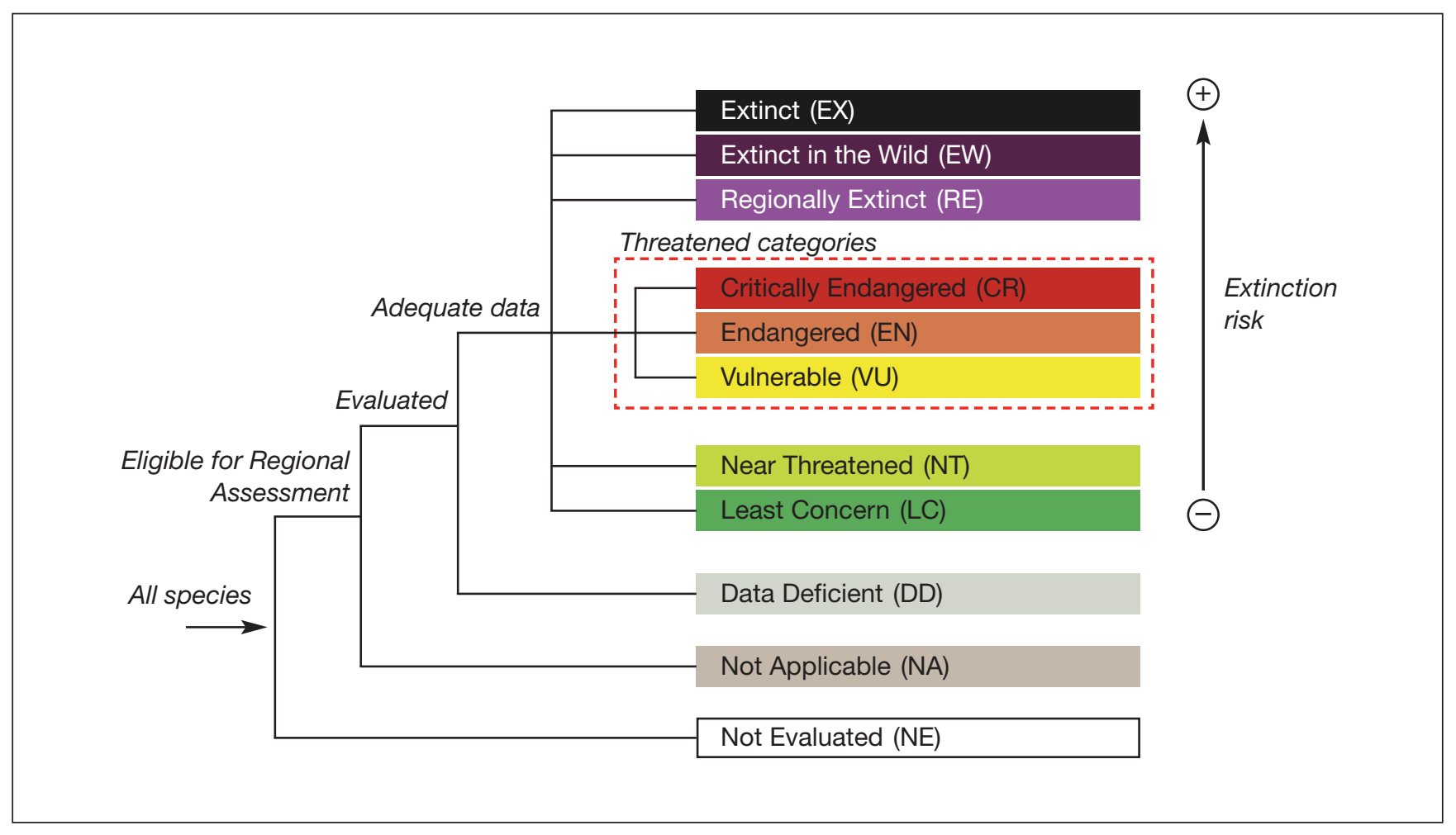

Figure 2. IUCN Red List Categories at the regional level (IUCN 2012b). For a description of each of the global IUCN Red List Categories go to: http://www.iucnredlist.org/technical-documents/categories-and-criteria/2001-categories-criteria. 
IUCN Red List assessments can be used as a tool for measuring and monitoring changes in the status of both biodiversity and our knowledge of the individual taxa. They are an essential basis for providing targets for management priorities, and for monitoring the long term success of management and conservation initiatives.

\subsection{The IUCN Red List Mediterranean initiative}

The extinction risk of a species can be assessed at a global, regional or national level. A taxon can have a different category in the Global Red List and a Regional Red List. For instance, a species which is common worldwide and listed as Least Concern (LC) in the Global Red List could face a high level of threat and meet the criteria of a threatened category, for example Endangered (EN), in a particular region. To avoid an over- or underestimation of the regional extinction risk of a species, the guidelines for the application of IUCN Red List Criteria at regional level (IUCN 2012b) should be applied. An endemic species should have the same category at the regional and global level, as it is not present in any other part of the world.

Therefore, the present regional assessment for the Mediterranean region not only evaluates the conservation status of this taxonomic group at the regional level, but also contributes to their more comprehensive assessment at the global level as it includes regional endemics.

\subsection{Geographical scope}

The assessment covers the Mediterranean region as considered by the Mediterranean basin hotspot (Mittermeier et al. 2004) with exception of the Macaronesian islands (Figure 1).

\subsection{Taxonomical scope}

This regional assessment evaluates a total of 460 native Mediterranean species. A checklist of all of these regionally assessed species is provided in Appendix 1. Taxonomy followed the Fauna Europaea (Fauna-eu.org; version 2012) for all species occurring in Europe. For all other species up-to-date literature was used, mainly Tshikolovets (2011).

\subsection{Data collection, assessment and review}

Information on habitats and ecology, distribution, threats and conservation measures, etc. was sourced and collated for all the butterflies occurring in the Mediterranean region. Experts from across the region were identified through the network of Butterfly Conservation. All the relevant and available information on each species was input into the IUCN species database (Species Information Service-SIS). Spatial data was sourced for the production of species distribution maps using ArcView GIS software.

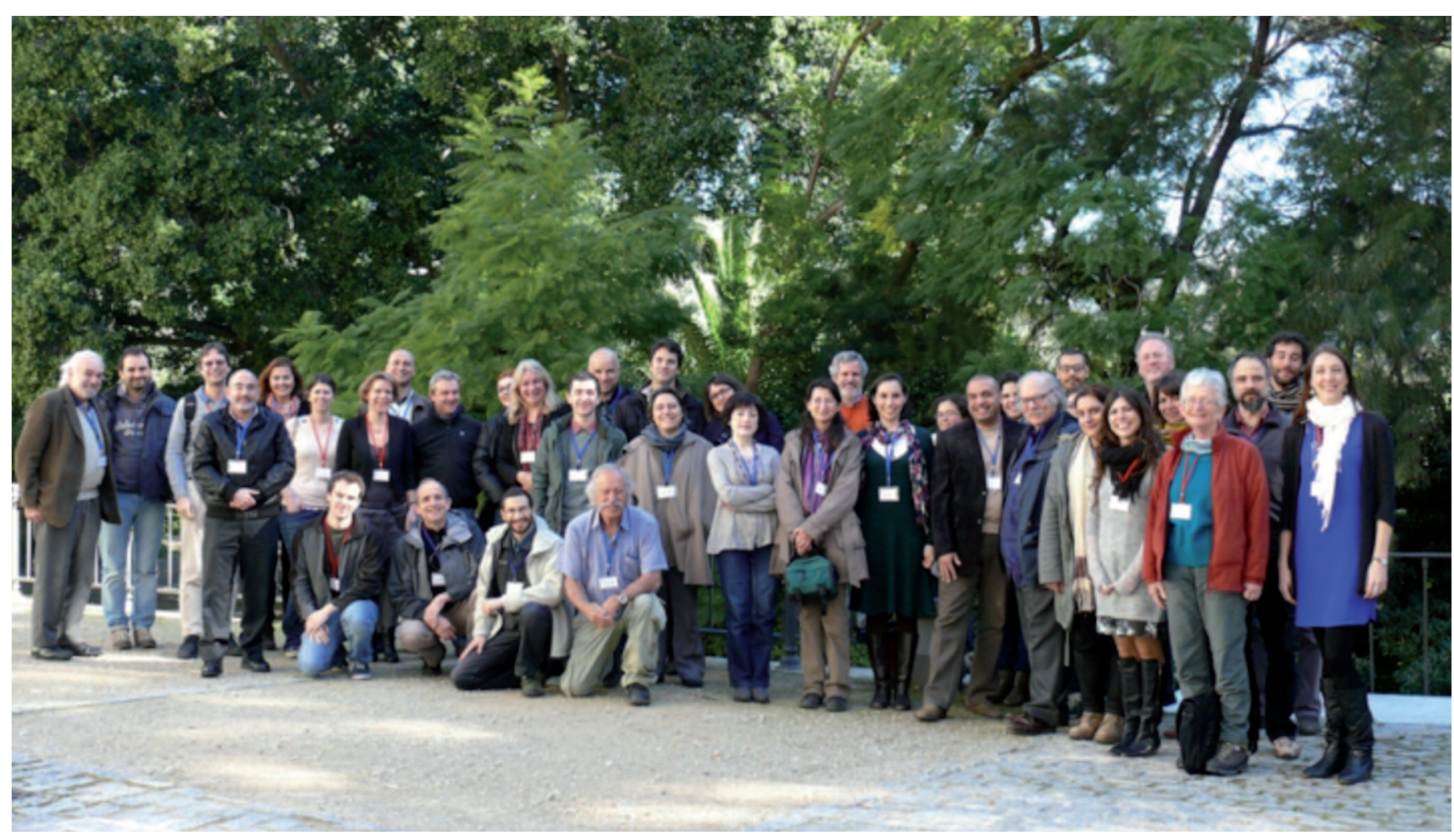

Expert participants at the Mediterranean Butterflies Red List workshop, February 2013, Malaga, Spain. @ Lourdes Lázaro/IUCN. 
The species information was then reviewed at a regional workshop where each species assessment was evaluated to ensure that the information presented was complete and correct, and that the Red List category had been applied correctly. The workshop was held in Málaga, Spain, in February 2013.

IUCN Red List assessments for 463 native species of butterflies present in the Mediterranean region were reviewed during the Málaga workshop. The status of each species was assessed according to the IUCN basic Red Listing procedures and documents, including the Guidelines for Application of IUCN Red List Criteria at Regional Levels (IUCN 2012b) and IUCN Red List Categories and Criteria (IUCN 2012a).

\subsection{Assessment review process}

All the Mediterranean butterfly assessments were finalised by June 2013. Experts from Mediterranean countries as well as from the IUCN Butterfly Specialist Group were then asked to review the species summary reports using a peer-review methodology. Their comments, together with any additional up-to-date information, were included in the assessments.

Supported by relevant data sources and by scientific literature, these final regional assessments are therefore the outcome of information exchange and agreement between the numerous Mediterranean specialists involved and their networks of informed colleagues.

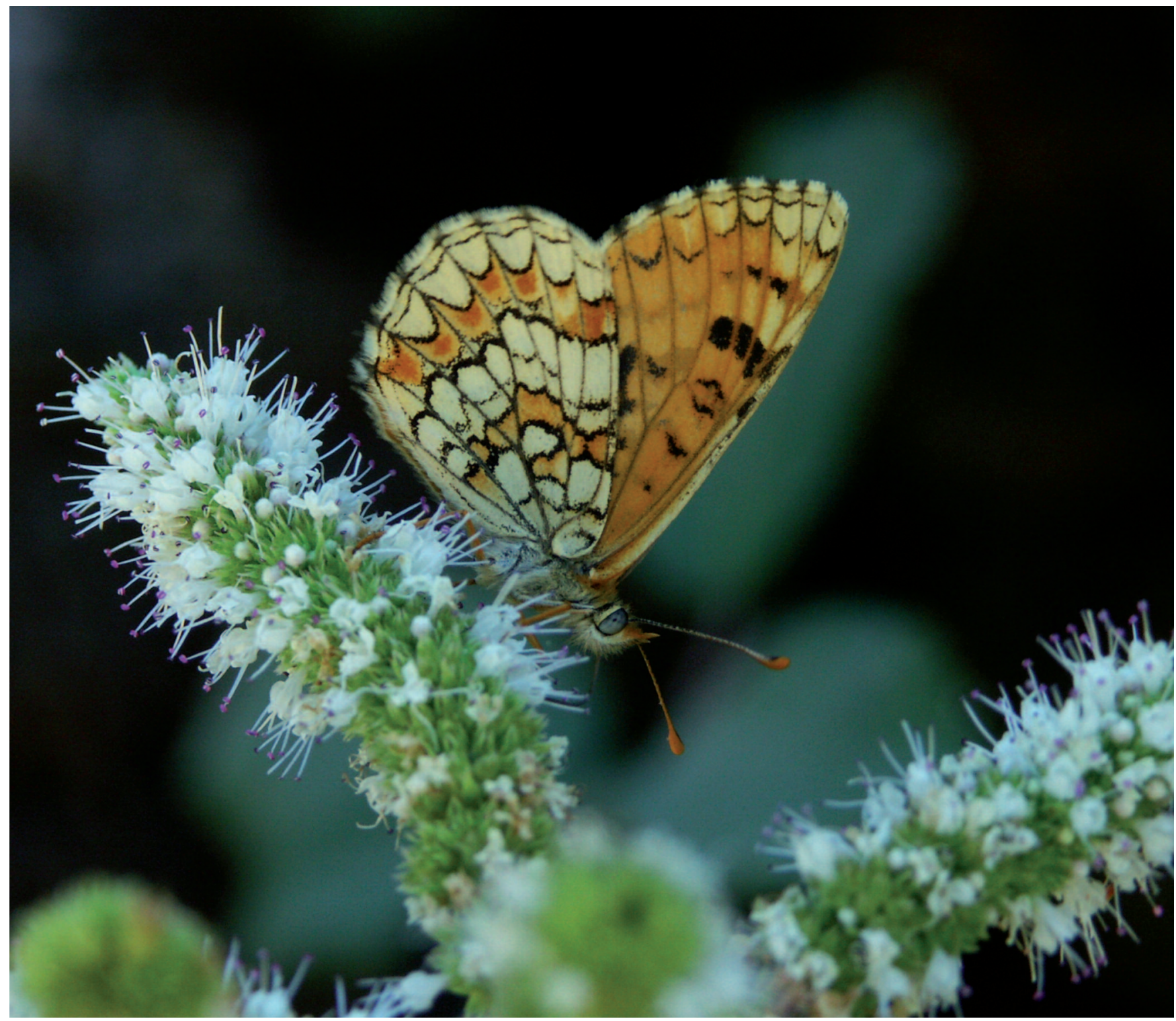

The Provençal Fritillary (Melitaea deione) is a widespread species in the Mediterranean where it occurs in all types of flower-rich, grassy places. (c) Chris van Swaay. 


\section{Chapter 3. Results and discussion}

3.1. Conservation status of Mediterranean butterflies

3.2. Endemic species

3.3. Threatened species

3.4. Near Threatened species

3.5. Data Deficient species

3.6. Least Concern species

3.7. Invasive species

3.8. Patterns of species richness

3.9. Major threats to butterflies in the Mediterranean region

\subsection{Conservation status of Mediterranean butterflies}

A total of 463 butterfly species in the Mediterranean region were regionally assessed. From this total, 34 species whose distributions in the Mediterranean region were less than $1 \%$ and one alien species were listed as Not Applicable and excluded from the rest of analysis. Nineteen (4.4\%) of the 428 remaining species were found to be threatened with extinction (Critically Endangered, Endangered or Vulnerable) in the region. Of these, 0.5\% (2 species) are listed as Critically Endangered (CR), which is the highest category of threat. A total of 3\% (13 species) are listed as Endangered (EN), 0.9\% (4 species) are listed as Vulnerable (VU). The status of these species must be

Table 2. Summary of the Red List status of butterflies in the Mediterranean region. Threatened categories are emphasized in colours.

\begin{tabular}{|lcc|}
\hline \multicolumn{1}{|c|}{ IUCN Red List Categories } & $\begin{array}{c}\text { No. native } \\
\text { species }\end{array}$ & $\begin{array}{c}\text { No. endemic } \\
\text { species }\end{array}$ \\
\hline Extinct & 0 & 0 \\
\hline Regionally Extinct (RE) & 2 & 0 \\
\hline Critically Endangered (CR) & 13 & 10 \\
\hline Endangered (EN) & 4 & 4 \\
\hline Vulnerable (VU) & 9 & 7 \\
\hline Near Threatened (NT) & 372 & 56 \\
\hline Least Concern (LC) & 28 & 20 \\
\hline Data Deficient (DD) & 35 & 0 \\
\hline Not Applicable (NA) & 463 & 98 \\
\hline Total number of species \\
in the Mediterranean
\end{tabular}

monitored particularly closely and, crucially, management and recovery plans should be implemented without delay. Further research and monitoring should also be conducted to better understand species' biology, threats and conservation needs. A further 2\% ( 9 species) of these species, are listed as Near Threatened (NT), suggesting that these species need to be monitored in case their conservation status becomes more serious.

Compared to butterflies, $14 \%$ of mammals, $19 \%$ dragonflies $13 \%$ of reptiles and $31 \%$ of amphibians are threatened at the Mediterranean level (Cuttelod et al. 2008). No other terrestrial groups have yet been comprehensively assessed at the Mediterranean level according to IUCN regional Red List guidelines.

The extent of gaps in the knowledge of Mediterranean butterflies can be identified by the numbers and proportions of species listed as Data Deficient (DD). This category means that there are not enough data available for these species to place them in one of the other Red List categories and does not imply that these species are not threatened. Six per cent $(28$ species) of Mediterranean butterfly species were listed as DD. This highlights the need for continued targeted research on these species. On a more positive note, $87 \%$ (372 species) of the butterflies in the Mediterranean are listed as Least Concern (LC), meaning that there is no immediate risk of extinction, and that population trends do not trigger the criteria for any of the threatened categories (Figure 3 and Table 2).

\subsection{Endemic species}

There are 98 butterfly species (21\%) which are endemic to the Mediterranean region. Fifteen of these species are threatened with extinction, which means that $79 \%$ of the threatened species in the Mediterranean region are endemic. One of the two species listed as Critically Endangered, the highest category of threat of extinction, is the endemic species Polyommatus bollandi. Ten endemic species are considered as Endangered and four species are listed as Vulnerable (Table 3). The percentage of Data 


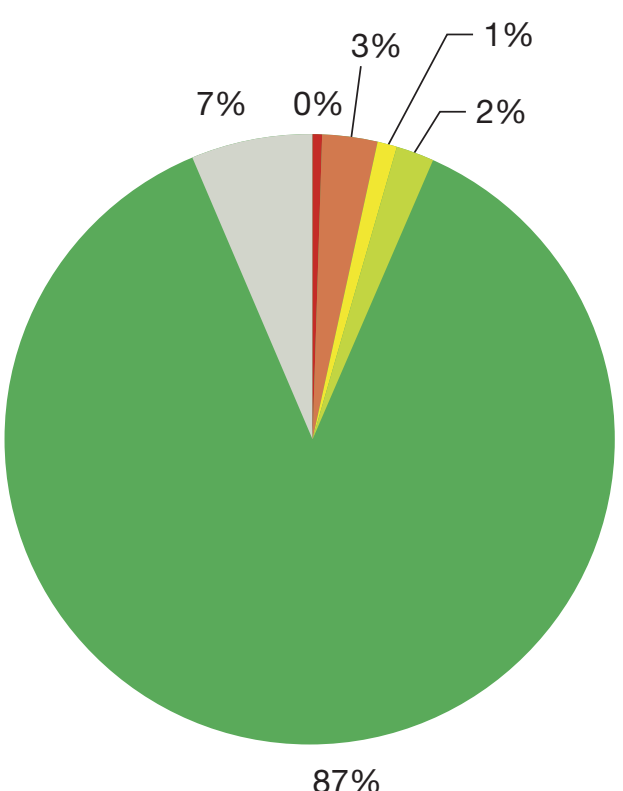

Figure 3. Red List status of butterflies in the Mediterranean region.

Table 3. Butterfly species listed as threatened at the Mediterranean regional level.

\begin{tabular}{llll}
\multicolumn{1}{c}{ Family } & \multicolumn{1}{c}{ Species name } & Category & Endemic \\
\hline Lycaenidae & Polyommatusbollandi & CR & endemic \\
\hline Lycaenidae & Polyommatus dama & CR & \\
\hline Hesperiidae & Spialia osthelderi & EN & \\
\hline Lycaenidae & Apharitiscilissa & EN & \\
\hline Lycaenidae & Plebejusvogelii & EN & endemic \\
\hline Lycaenidae & Plebejuszullichi & EN & endemic \\
\hline Lycaenidae & Polyommatustheresiae & EN & endemic \\
\hline Lycaenidae & Pseudophilotesfatma & EN & endemic \\
\hline Nymphalidae & Arethusanaaksouali & EN & endemic \\
\hline Nymphalidaee & Hipparchiachristenseni & EN & endemic \\
\hline Nymphalidae & Hipparchiasbordonii & EN & endemic \\
\hline Nymphalidae & Lasiommatameadewaldoi & EN & endemic \\
\hline Nymphalidae & Maniolahalicarnassus & EN & endemic \\
\hline Nymphalidae & Pseudochazaraamymone & EN & endemic \\
\hline Pieridae & Coliascaucasica & EN & \\
\hline Lycaenidae & Polyommatusgolgus & VU & endemic \\
\hline Lycaenidae & Polyommatusiphicarmon & VU & endemic \\
\hline Lycaenidae & Polyommatuslycius & VU & endemic \\
\hline Pieridae & Pierissegonzaci & VU & endemic \\
\hline
\end{tabular}

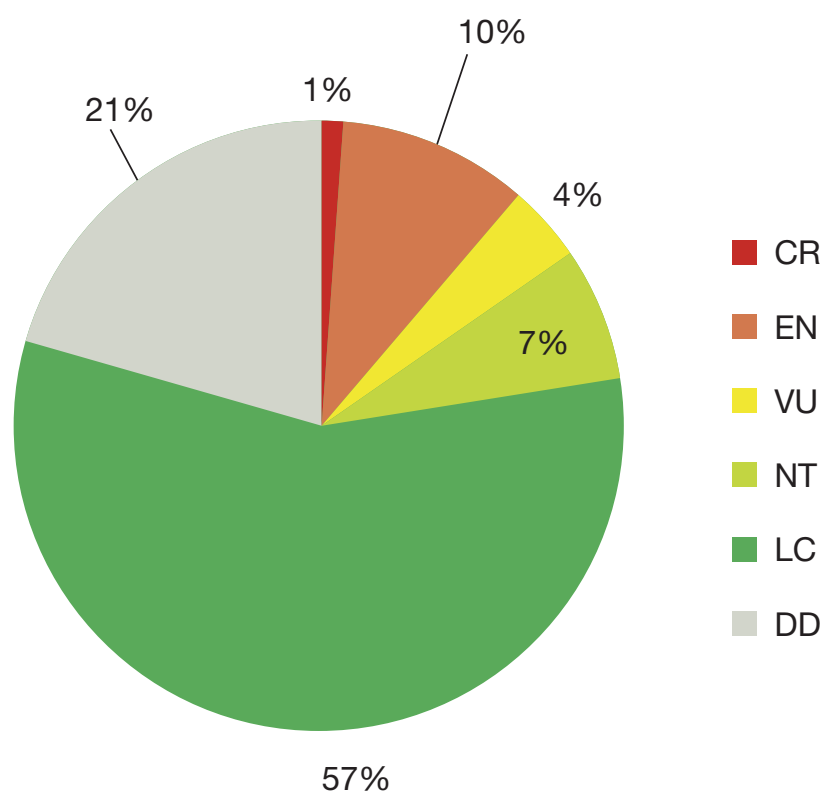

Figure 4. Red List status of Mediterranean endemic butterflies.

Deficient endemic species is $20 \%$, which is higher than the percentage of Data Deficient butterflies in general. This suggests that endemic species in the Mediterranean region are generally not very well known or studied, and generally less so than most of the more widely distributed species.

\subsection{Threatened species}

Nineteen species assessed in this report are threatened, belonging to one of the three IUCN threat categories (Critically Endangered, Endangered and Vulnerable) (Table 3), which represents $4.4 \%$ of the species assessed. However the proportion of threatened butterfly species is uncertain given the number of Data Deficient species, and could lie between $4.4 \%$ (if all DD species are not threatened) and 11\% (if all DD species are threatened) for the Mediterranean (Table 4). Thus, the midpoint figures provide the best estimation of the proportion of threatened species (IUCN 2011), which in this case is $4.8 \%$.

Table 4. Proportion of threatened species in the Mediterranean region.

\begin{tabular}{lc} 
& \% threatened \\
\hline $\begin{array}{l}\text { Lower bound } \\
(\mathrm{CR}+\mathrm{EN}+\mathrm{VU}) /(\text { assessed }-\mathrm{EX})\end{array}$ & 4.4 \\
\hline $\begin{array}{l}\text { Mid-point } \\
(\mathrm{CR}+\mathrm{EN}+\mathrm{VU}) /(\text { assessed }-\mathrm{EX}-\mathrm{DD})\end{array}$ & 4.8 \\
\hline $\begin{array}{l}\text { Lower bound } \\
(\mathrm{CR}+\mathrm{EN}+\mathrm{VU}+\mathrm{DD}) /(\text { assessed }-\mathrm{EX})\end{array}$ & 11 \\
\hline
\end{tabular}


It should be noted that the percentages of threatened butterflies mentioned above represent minimum estimates. If we consider only those species that are surviving and for which we have enough data to assess the risk of extinction (excluding DD and NA species), we might receive a more realistic value, assuming that the percentage of threat among DD species is similar to the overall percentage of threatened species within this group. In this case, $4.8 \%$ of the assessed butterflies are threatened at Mediterranean level.

Seriously threatened species listed as Critically Endangered include the Bolland's Blue, Polyommatus bollandi, a species restricted to the southwestern edge of the Amanos Mountains, and the Mesopotamian Blue, Polyommatus dama, both endemic to Turkey. Urbanization, building of dams, roads, mining, overgrazing and pollution are the main threats to these species. Three additional species from Turkey and the Levant region are listed as Endangered: the Levantine Silver Line (Apharitis clisa), the Osthelder's Skipper (Spialia osthelderi), and the Theresia's Blue (Polyommatus theresiae) are affected by habitat degradation caused by increasing irrigation, pesticide use, and urbanization. There are four more species listed as Endangered from the Balkans and Greece. The Halicarnas Brown (Maniola halicarnasus), the Karpathos Grayling (Hipparchia christenseni), the Brown's Grayling (Pseudochazara amymone) and the Balkan Clouded Yellow (Colias caucasica), all live in scattered clearings and areas with shrubby vegetation; they are affected by habitat loss and degradation caused by fires, urbanization, and infrastructure development. In Morocco, four species are also listed as Endangered: the Vogel's Blue (Plebejus vogeli), the Fatma's Blue

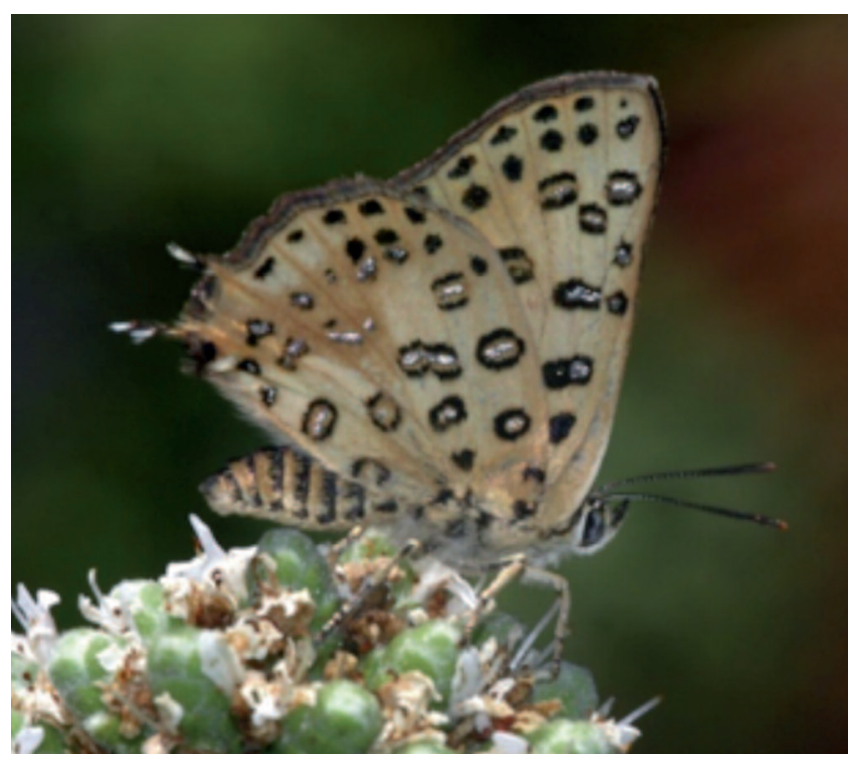

The Levantine silver-line (Apharitis cilisa), classifed as Endangered, is threatened by agricultural intensification in southern Turkey, where irrigation and more intensive land use follows large dam schemes, allowing cultivation of new areas previously considered too dry, and resulting in the use of herbicides and pesticides. In Israel an ongoing decline in the species' distribution has been documented due to urban expansion in the coastal plains. (C) Ali Atahan.
(Pseudophilotes fatma), the Atlas Grayling (Arethusana aksouali) and the Moroccan Wall Brown (Lasiommata meadewaldoi). With only one or a few subpopulations, these species occur in high altitude mountains and are currently affected by habitat degradation, caused mainly by overgrazing. In Italy, the Ponza Grayling, Hipparchia sbordonii, is endemic to the Ponza islands and has a very restricted range on a few isolated islands. It is subject to strong pressures from tourism, urbanization and fires, which have led to this species being listed as Endangered. In Spain, the Zullich's Blue (Plebejus zullichi), listed as Endangered, is restricted to high altitudes in Sierra Nevada. Although its distribution range is included in a protected area, the species is still affected by overgrazing, trampling and infrastructures. Four butterfly species are listed as Vulnerable in the region: the Sierra Nevada Blue (Polyommatus golgus), an endemic from southern Spain restricted to a few mountain ranges, threatened by habitat reduction due to climate change and tourism infrastructure development; two endemics from Turkey, the Iphacarmon Blue (Polyommatus iphicarmon), threatened by a series of factors which include active forestry, grazing activities and conversion of mountain grasslands to agriculture, and the Lycian Blue (Polyommatus lycius), restricted to the Bey Mountains and threatened by pesticide use in agriculture; finally, the Moroccan Green-veined White (Pieris segonzaci), restricted to the High Atlas, affected by habitat degradation due to overgrazing.

\subsection{Near Threatened species}

Overall, nine species (2.1\%) were assessed as Near Threatened (NT), reflecting concern that they are close to qualifying for a threatened category and could do so in the near future. It is essential that these species are monitored closely and, where possible, management action should be taken to avoid their becoming listed as threatened in the future. Seven of the nine species listed as Near Threatened species are endemic to the Mediterranean region. The Panoptes Blue (Pseudophilotes panoptes) is an Iberian endemic apparently highly susceptible to the current trends of climate change. The Atlas Blue (Polyommatus atlanticus) and the Vaucher's Heath (Coenonympha vaucheri), two species restricted to mountain ranges in Morocco and Algeria, are affected by overgrazing in their distribution range, because their host plants are preferred by domestic herbivores. The Odd-Spot Blue (Turanana taygetica) and the Chios Meadow Brown (Maniola chia), two endemics from Greece, are affected by the abandonment of traditional agriculture, quarrying and tourism, and by fires and collection respectively. In Italy, an endemic from the Aeolian Islands, the Aeolian Grayling (Hipparchia leighebi) lives in small areas which are exposed to fires. In Turkey, the Beautiful Blue (Polyommatus guezelmavi), an endemic from the Geyik Mountains, is exposed to extensive agricultural intensification and climate change. Two non-Mediterranean endemic species from Turkey and Levant are also listed as Near Threatened in the region. The Orange-banded Hairstreak (Satyrium ledereri) and the Anatolian False Argus (Aricia hyacinthus) are affected by fire and overgrazing respectively. 


\subsection{Data Deficient species}

This IUCN Red List assessment of all native butterflies has confirmed that there is a significant lack of information on the status of many species in the region. More than six per cent of species assessed are categorized as Data Deficient (DD). This indicates that there is insuficient information available to enable accurate assessment of their extinction risk. It is usually as a result of taxonomic uncertainty or because the species has an unknown or poorly known geographic distribution. It is important to remember that some of these DD species may be threatened by anthropogenic threats. Research efforts focusing on species for which there is currently little knowledge must therefore be urgently increased, because Data Deficient listing does not mean that these species are not threatened. In fact, as knowledge improves, such species are sometimes found to be amongst the most threatened. It is therefore essential to direct research effort and funding towards these species, as well as to those in the threatened categories. This is particularly important when there are apparent threats but no available data on population sizes or biological parameters.

\subsection{Least Concern species}

There are 372 butterfly species (87\%) listed as Least Concern (LC) in the Mediterranean; they are not considered to be under any known major threat of extinction now or in the foreseeable future. Many of these species are generally abundant and/or relatively widespread; have their main distribution outside intensively used agricultural areas and/or are relatively productive and resilient to other current threats and pressures. Some of these species may still benefit from conservation management action, however, even though they are listed as LC.

\subsection{Non-native species}

At the moment there is only one invasive butterfly species in the Mediterranean: Cacyreus marshalli. Since its accidental introduction to Mallorca in 1988, it has been spreading rapidly through the Western Mediterranean, later also heading east through Southern Europe. At the moment it has reached Turkey and it shows no sign of stopping, unless it gets to areas where no Pelargoniums are planted in urban areas (Soyhan et al. 2013).

\subsection{Patterns of species richness}

Butterfly distribution in the Mediterranean is not homogeneous. Figure 5 highlights areas of high concentrations of butterfly species diversity. The highest species richness is found in mountainous areas where high diversity of microclimates

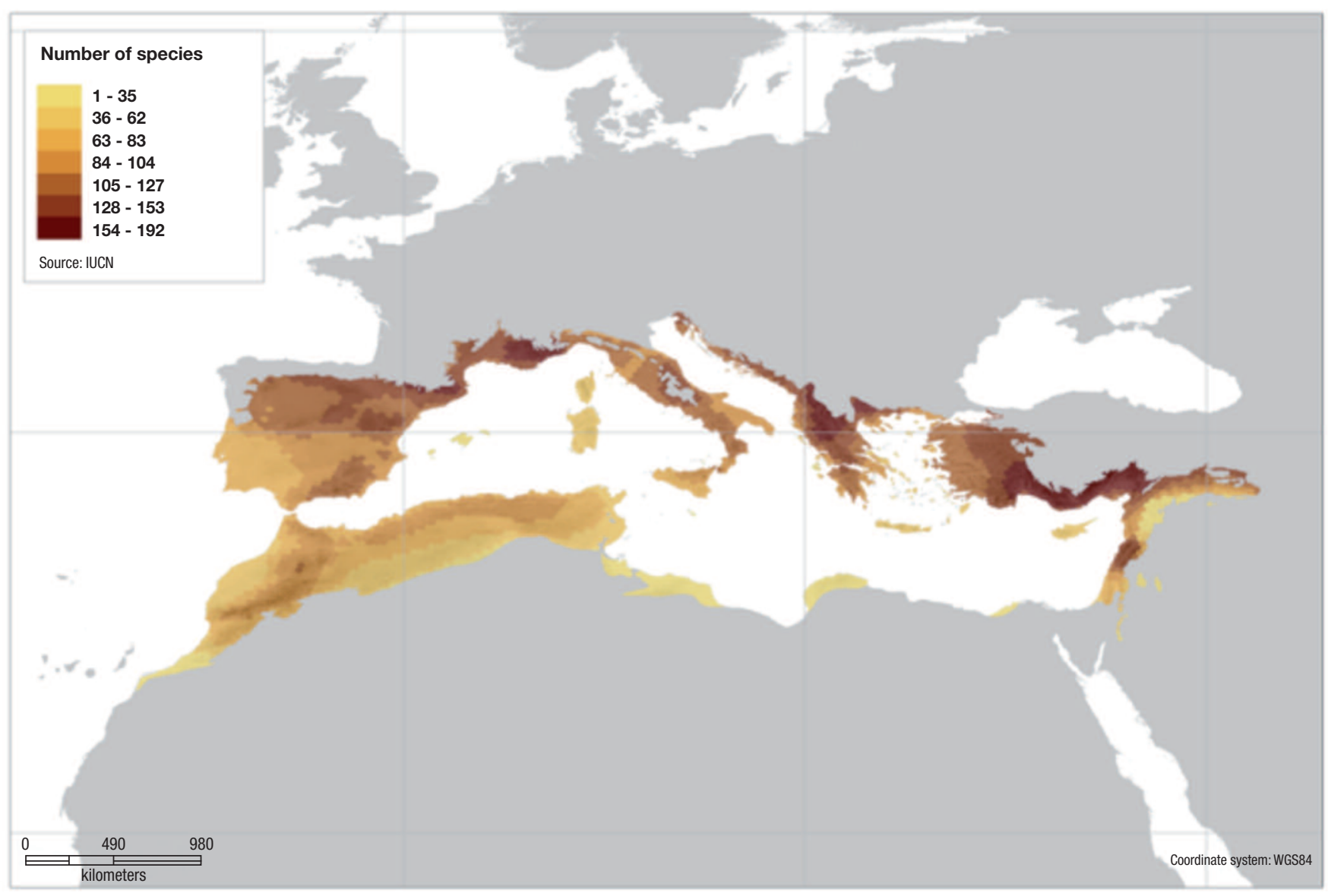

Figure 5. Species richness of butterflies in the Mediterranean region. 
favours many species adapted to different microhabitats, e.g. in southern France, the higher parts of northern Greece as well as southern Turkey.

A relatively high percentage $(21 \%)$ of the Mediterranean butterflies are endemic to the region. This level of endemism is higher than for example the level existing in the countries of the European Union (17\%) (van Swaay et al. 2010). The majority of the endemic species are concentrated in the north of Africa, especially in the Rif Mountains, the High and Middle Atlas Mountains in Morocco, and the Aurès Mountains in Algeria. There are also important zones with endemism in the southeast of Spain (Sierra Nevada and Sierra of Baza), on the islands of Corsica and Sardinia, in southern Turkey and in Lebanon (Figure 6).

The proportion of threatened species in the Mediterranean is slightly lower than in the European Union (6.6\%) and on the European continent $(7.7 \%)$. The relatively low proportion of threatened species, when compared with the results from some other regional assessments, was thought to be due to the higher area of remaining natural and semi-natural habitats, as well as the use of traditional agriculture practices in comparison with these other regions.

There are a few areas with high concentrations of threatened species (Figure 7). These areas coincide mainly with high elevations in south-eastern Spain, the High and Middle Atlas Mountains, northern Greece and southern Turkey in the AntiTaurus Mountains.

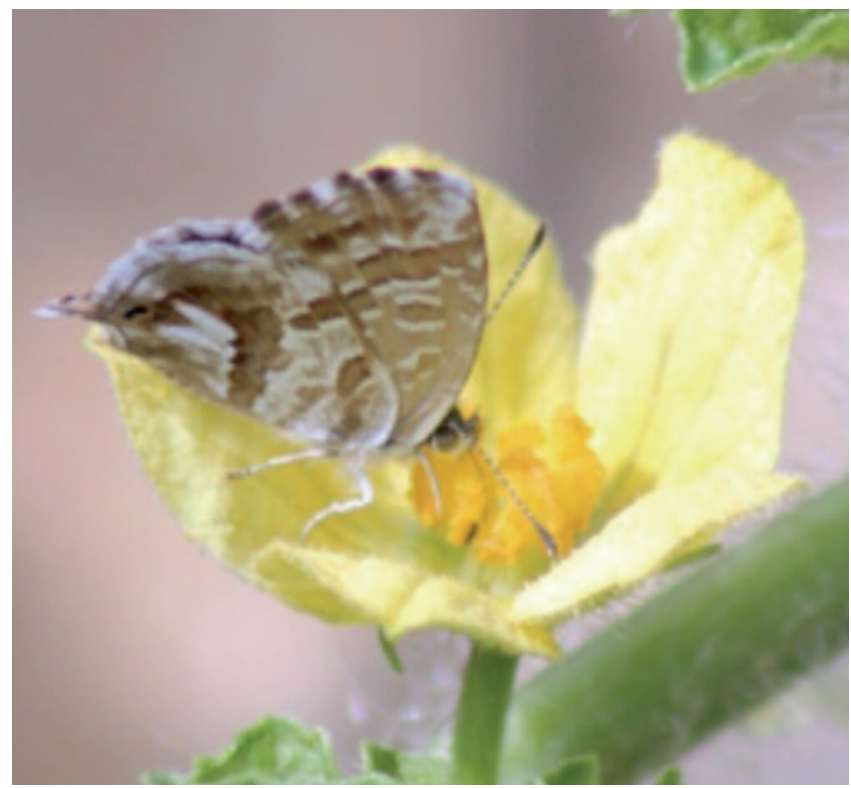

The Geranium Bronze (Cacyreus marshalli) was introduced to the Balearic Islands in 1988 and is rapidly spreading across the Mediterranean. (C) Finlay Cox (Source: inaturalist.org).

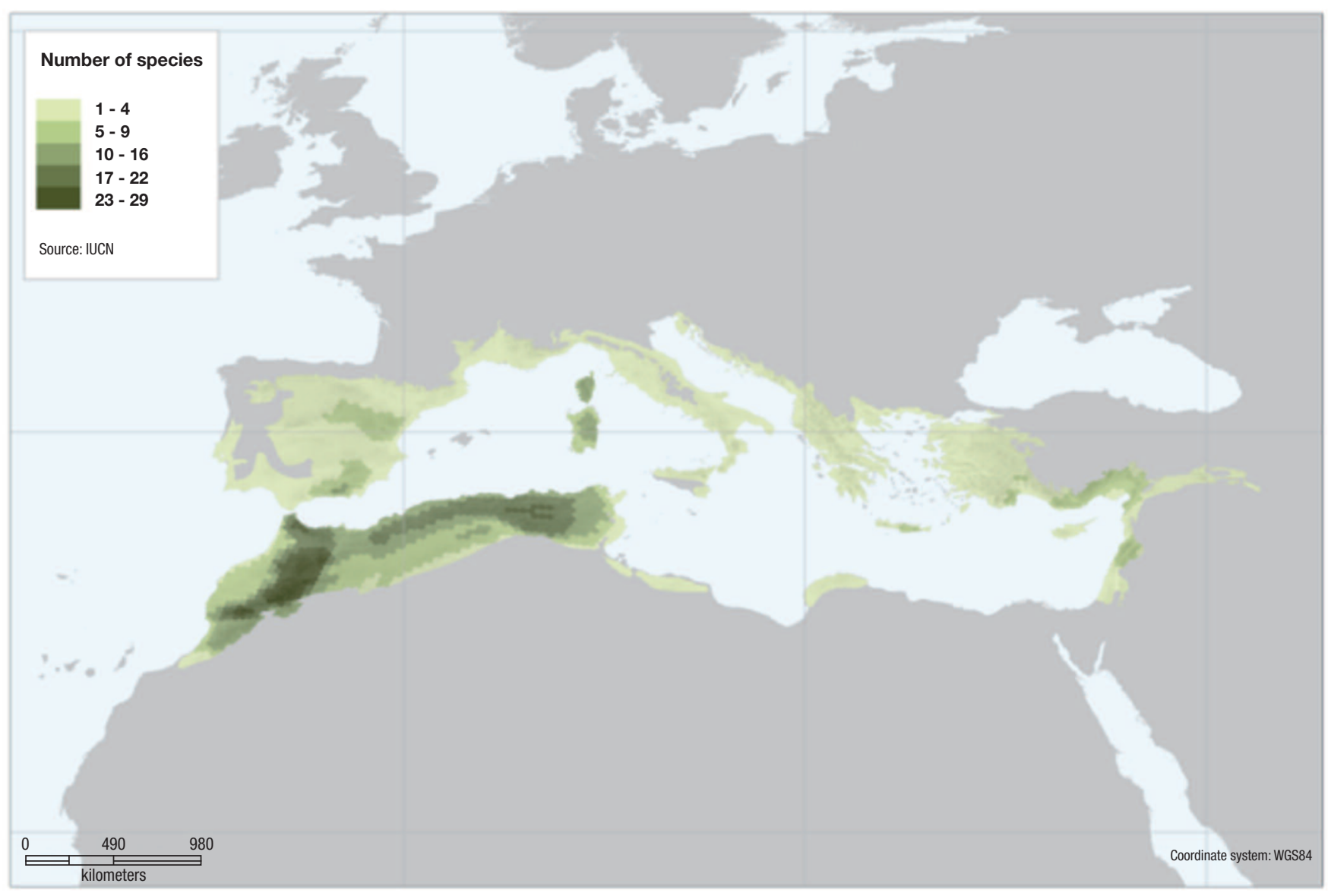

Figure 6. Species richness of endemic butterflies in the Mediterranean region. 


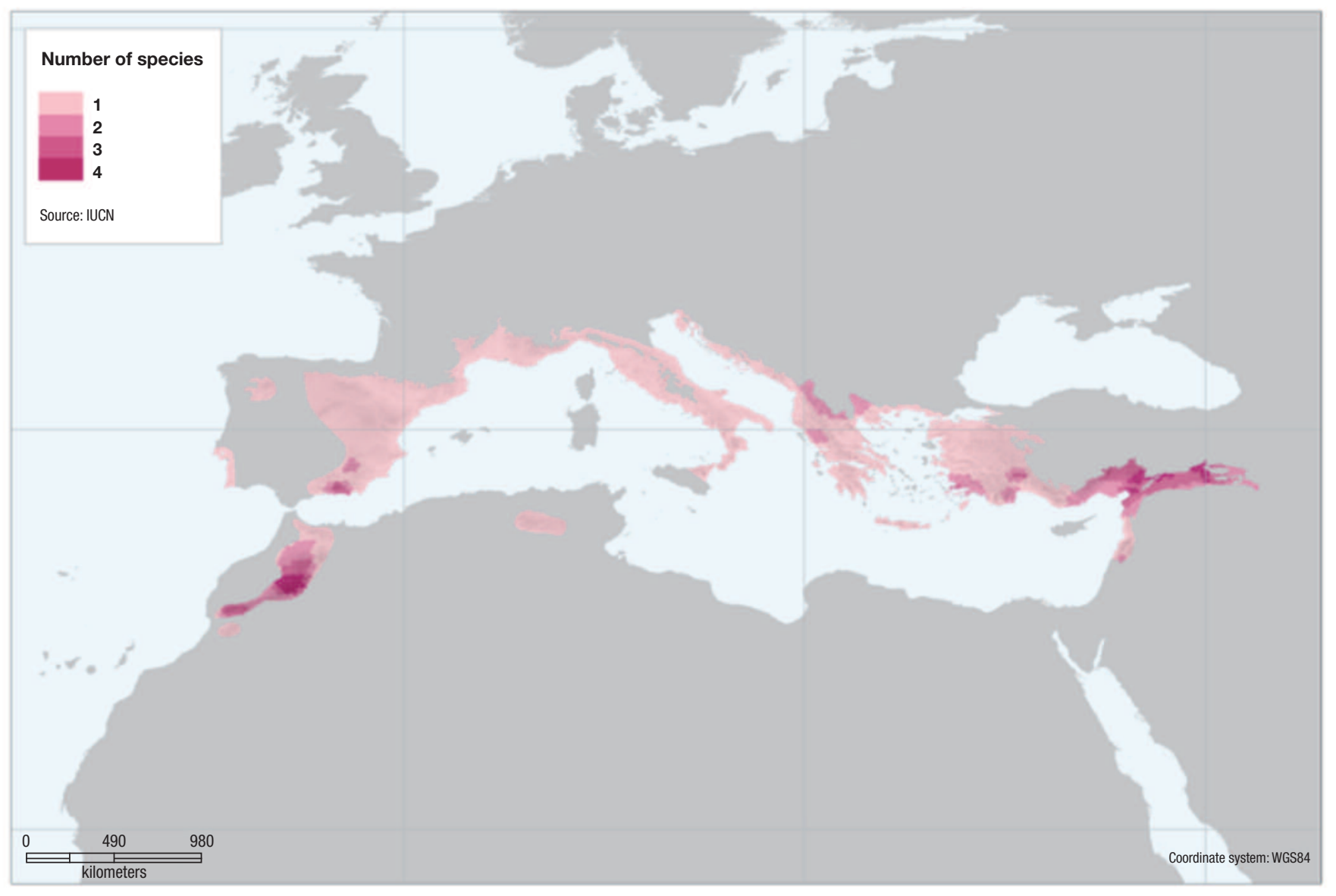

Figure 7. Distribution of threatened butterflies in the Mediterranean region.

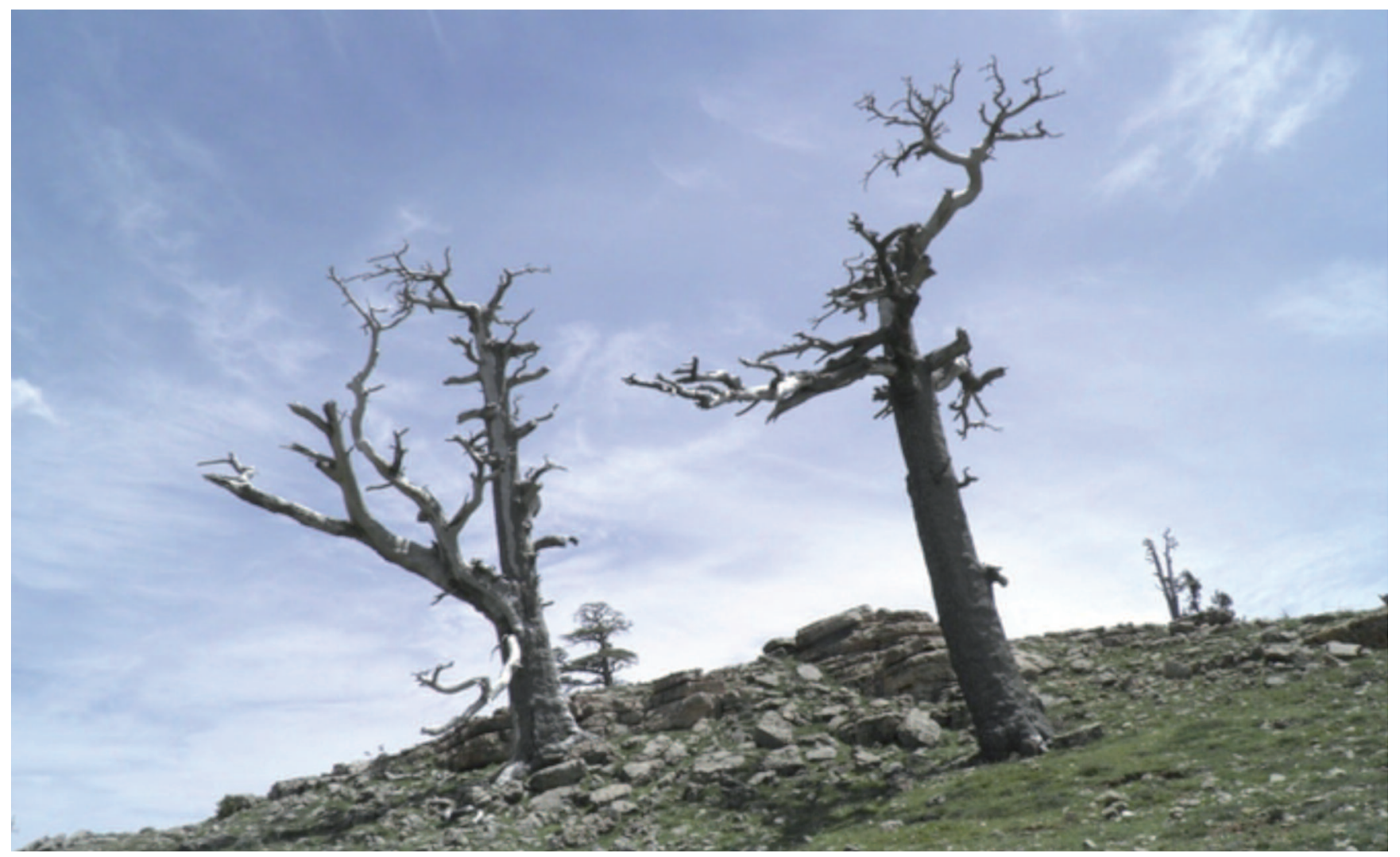

In some regions of the Mediterranean, overgrazing is one of the main threats to butterflies, as seen here at Timahdite, in Morocco. (c) Rudi Verovnik. 
Agriculture \& aquaculture

Natural system modifications

Residential \& commercial development

Biological resource use

Climate change \& severe weather

Pollution

Human intrusions \& disturbance

Transportation \& service corridors

Energy production \& mining

Invasive \& other problematic species \& genes
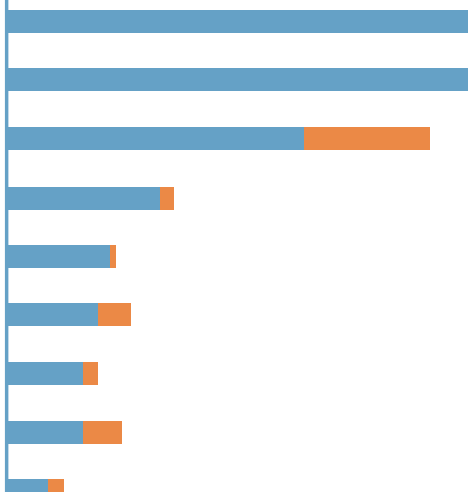

$\begin{array}{lllllllllll}0 & 20 & 40 & 60 & 80 & 100 & 120 & 140 & 160 & 180 & 200\end{array}$

All Taxa Threatened Taxa

Figure 8. Summary of threats to all native species assessed in the Mediterranean region.

\subsection{Major threats to butterflies in the Mediterranean region}

A summary of the major threats to butterflies in the Mediterranean, according to the IUCN Classification Scheme of Threats, is presented in Figure 8. The main threat to Mediterranean butterflies is agricultural intensification, which involves changes in the management of semi-natural grasslands and overgrazing. The conversion of grasslands into agricultural land for arable farming or forestry is a serious threat leading to habitat loss and degradation. Unsustainable levels of grazing and livestock abandonment are also important threats for Mediterranean butterflies. On one hand, overgrazing reduces the availability of nutritious plants and refuge for larvae, and on

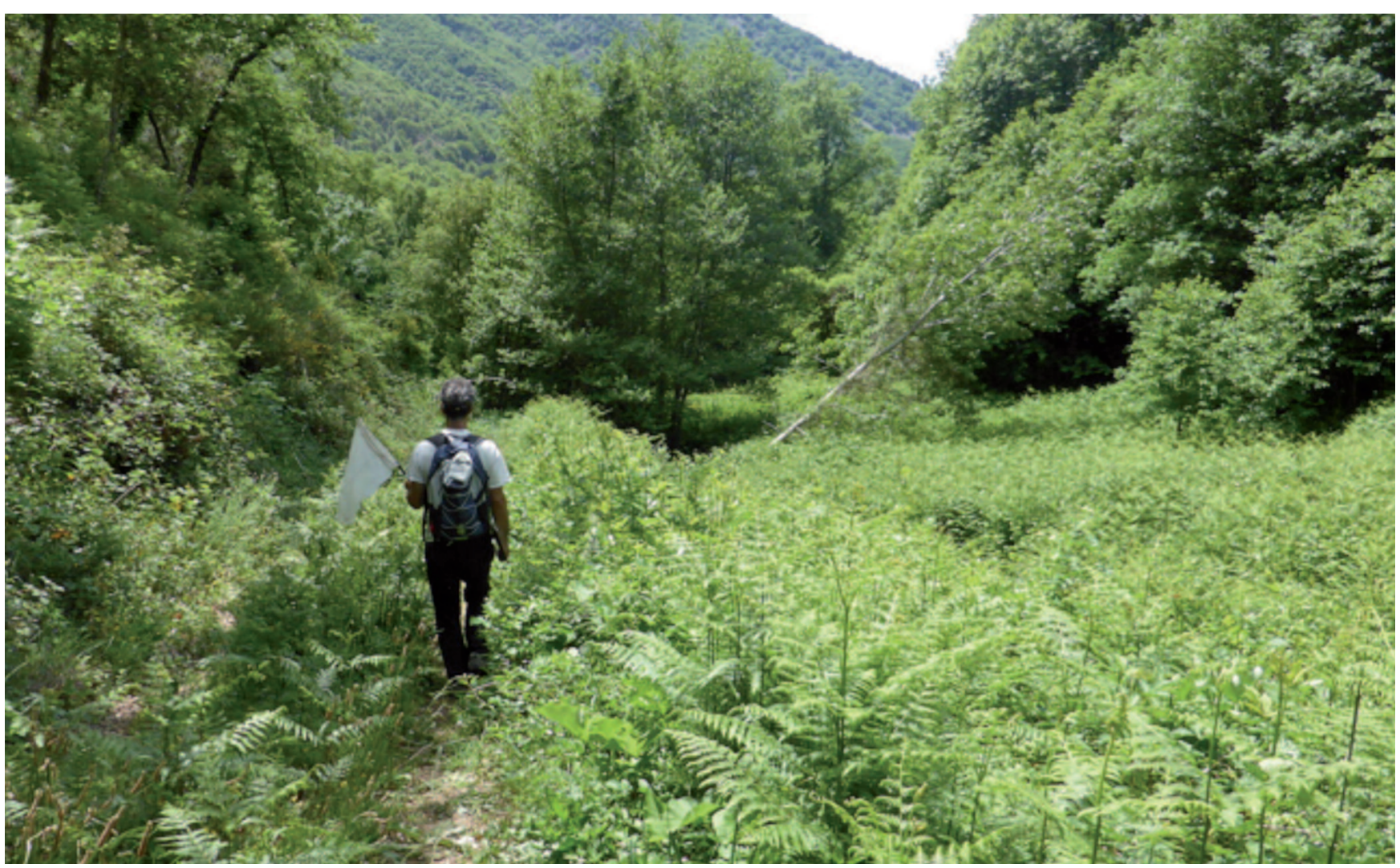

Former grasslands, which were very rich in butterflies, get overgrown with ferns after being abandoned. Almost all species show a massive decline here. Massis del Montseny, Spain, 2015. (c) Chris van Swaay. 
the other hand, land abandonment leads to former grassland getting overgrown with shrubs, turning later into secondary forest and thereby reducing suitable habitat for most butterfly species.

Overgrazing and agriculture intensification is reported to be one of the major threats to butterflies, especially in Morocco. Recently this has worsened and in some regions butterfly numbers have dropped to very low levels. In some parts of the Mediterranean, especially in parts of southern Europe, land abandonment is a problem, especially for butterflies relying on semi-natural grasslands (which need some form of lowintensity agricultural use).

Tourism development is an important driver of habitat loss, especially for some of the threatened species, such as Polyommatus golgus and Plebejus zullichi, in the high mountains of Sierra Nevada, in Spain, where ski development can threaten some of the populations.

Over-exploitation of larval foodplants and nectar sources, as well as deforestation, are also important threats for many species. Although collecting is a minor threat to most butterflies, a few species are attractive to collectors. For threatened populations of these species, collecting can be an extra pressure and should therefore be avoided.

Climate change is another important threat to butterflies in the Mediterranean region. One of the possible scenarios is a northward extension of the Sahara desert, leading to arid conditions in northern Africa and possibly even in southern Europe. Climate change will also force mountain species higher up (Wilson et al. 2007). The pace of change will almost certainly be more rapid than most butterflies are able to migrate (see also Devictor et al. 2012).

Other threats have a smaller impact, but can still be important locally or for some species. Domestic and agricultural pollution can destroy small habitats and lead to faster vegetation succession, reducing the area of suitable habitat. Transportation and service corridors fragment butterfly habitats, reducing the likelihood of maintaining a viable population structure. Mining can locally destroy butterfly habitat. However, as far as we know, butterflies in the Mediterranean region are in general hardly affected by invasive species or parasites.

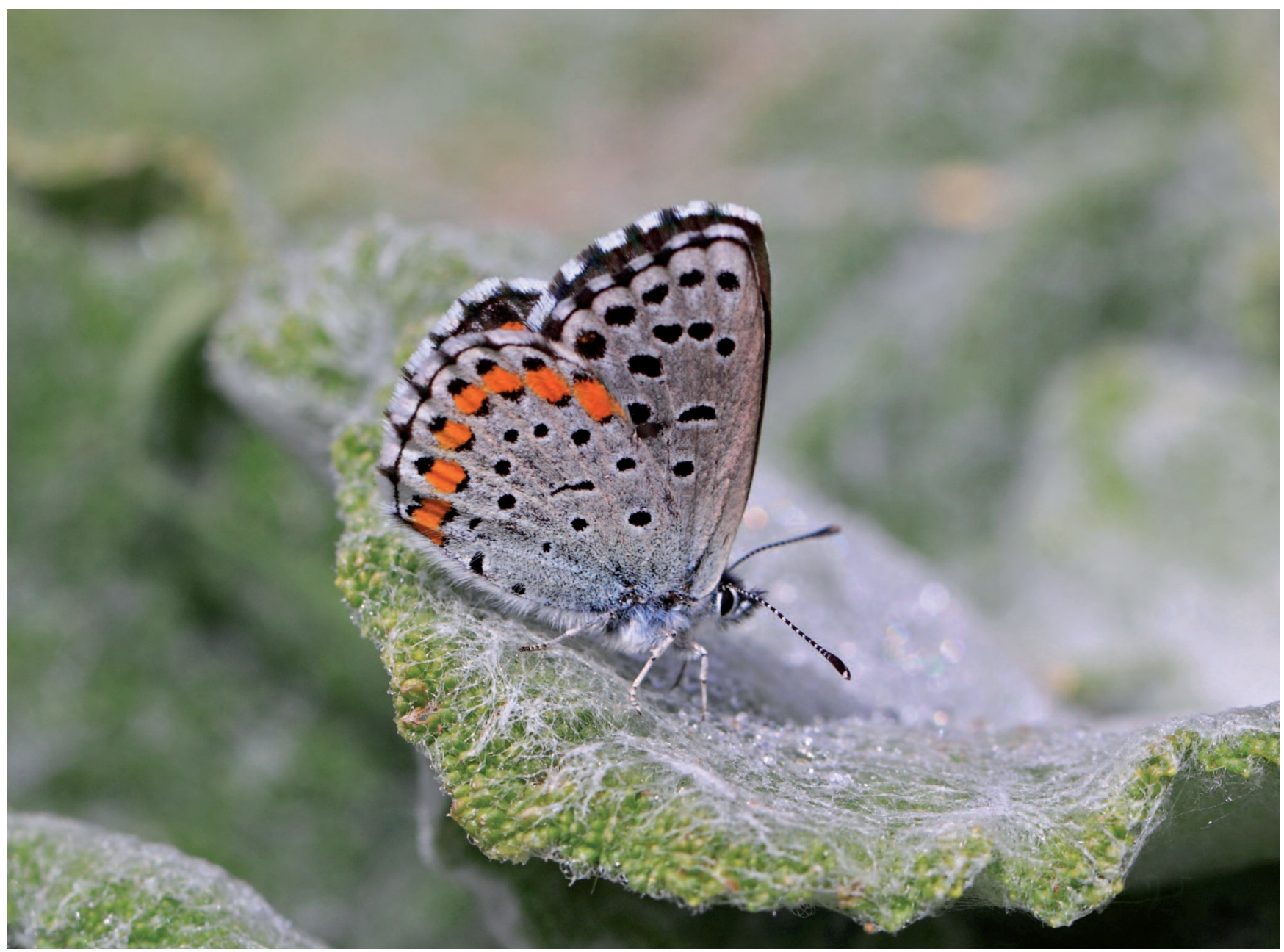

The Fatma's Blue (Pseudophilotes fatma), endemic to North Africa, is listed as Endangered due mainly to overgrazing. (c) Rudi Verovnik. 


\section{Chapter 4. Recommendations for priority conservation measures}

4.1. International and regional instruments relevant to the conservation and management of Mediterranean butterflies ......... 15

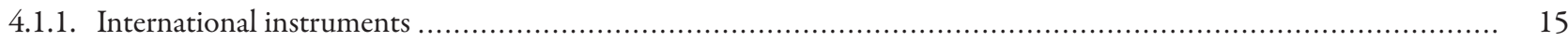

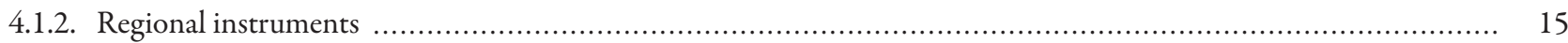

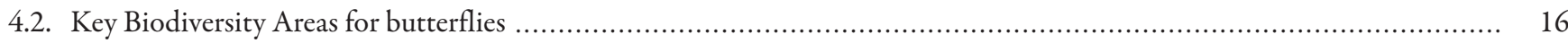

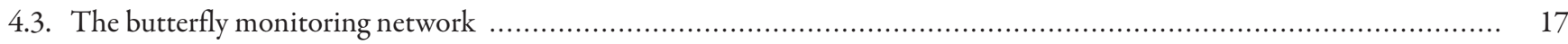

4.4. Strategic planning for Mediterranean species conservation: action plans for butterfly species in Sierra Nevada, Spain ....... 17

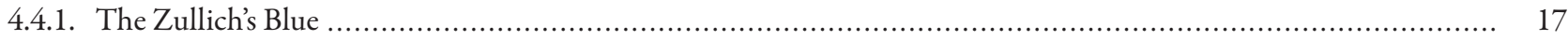

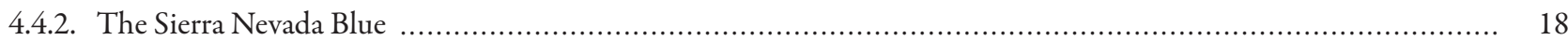

Some protection measures are currently in place, either for species or ecosystems, in the Mediterranean region. National protection status varies according to country, and there is an urgent need to implement conservation actions. The following section presents current conservation initiatives, as well as priority recommendations for the conservation of Mediterranean butterfly biodiversity.

\subsection{International and regional instruments relevant to the conservation and management of Mediterranean butterflies}

Mediterranean countries are signatories to a number of important conventions aimed at conserving biodiversity. The following conventions are relevant to the conservation and management of the Mediterranean insect fauna under various regional and international conventions, which are summarised in Table 5. Only one of the species listed in the appendices of international or regional conventions, Polyommatus golgus, is threatened in the Mediterranean region.

The Bern Convention is a binding international legal instrument that aims to conserve wild flora and fauna and their natural habitats and to promote European cooperation towards that objective. It covers all European countries and some African states. There are 10 Mediterranean species of butterflies listed under its Annex II (strictly protected species).

The Habitats Directive is one of the EU's two directives related to wildlife and nature conservation. There are 12 Mediterranean butterflies listed in its Annexes II (species requiring designation of Special Areas of Conservation) and IV (species in need of strict protection).

The Convention on International Trade in Endangered Species of Wild Fauna and Flora (CITES) prevents trade in endangered species of wild fauna and flora. Two species of butterflies, Papilio hospiton and Parnassius apollo, are listed in this convention, in Appendix II (species which may become so unless trade is closely controlled).

\subsubsection{International instruments}

The Convention on International Trade in Endangered Species of Wild Fauna and Flora (CITES)

CITES was established in recognition that international cooperation is essential for the protection of certain species from over-exploitation through international trade. It creates the international legal framework for the prevention of trade in endangered species of wild fauna and flora and for the effective regulation of international trade in other species which may become threatened in the absence of such regulation. CITES Appendix II lists species that are not currently endangered, but their trade must be controlled to avoid endangering the species. The Apollo butterfly (Parnassius apollo) and the Corsican Swallowtail (Papilio hospiton) are the only butterflies included in Appendix II of the CITES, which occur in the Mediterranean region.

\subsubsection{Regional instruments}

The Bern Convention on the Conservation of European Wildlife and Natural Habitats

The Bern Convention aims to conserve wild flora and fauna and their natural habitats, especially where the cooperation of several States is required (Council of Europe 2016). The main aim of the EC Habitats Directive is to promote the maintenance of biodiversity. The Directive requires Member States to take measures to maintain or restore natural habitats and wild species (listed in its Annexes) to a favourable conservation status, introducing robust protection for those habitats and species of European importance. This requires measures to be taken to 
Table 5. Legal protection of butterflies at international and regional level in the Mediterranean

\begin{tabular}{|c|c|c|c|c|c|}
\hline \multirow[b]{2}{*}{ Species } & \multirow[b]{2}{*}{$\begin{array}{l}\text { IUCN } \\
\text { Red List } \\
\text { Category at the } \\
\text { Mediterranean } \\
\text { level }\end{array}$} & \multirow{2}{*}{$\begin{array}{l}\quad \begin{array}{l}\text { International } \\
\text { Legal Instrument }\end{array} \\
\text { CITES (a) Convention } \\
\text { on International Trade } \\
\text { in Endangered Species } \\
\text { of Wild Fauna and Flora } \\
\text { (1975) }\end{array}$} & \multirow{2}{*}{$\begin{array}{l}\qquad \begin{array}{l}\text { Regional } \\
\text { Legal Instrument }\end{array} \\
\text { Bern Convention (b) } \\
\text { Convention on the } \\
\text { Conservation of European } \\
\text { Wildlife and Natural } \\
\text { Habitats (1979) }\end{array}$} & \multicolumn{2}{|c|}{$\begin{array}{c}\text { European } \\
\text { Legal Instrument }\end{array}$} \\
\hline & & & & $\begin{array}{l}\text { EU Habitats } \\
\text { Directive (c) }\end{array}$ & $\begin{array}{l}\text { EU regulation } \\
\text { on the trade in wild } \\
\text { fauna and flora } \\
\text { species }(d)\end{array}$ \\
\hline Plebicula golgus & VU & & II & II/IV & \\
\hline Apatura metis & $\mathrm{LC}$ & & II & IV & \\
\hline Argynnis elisa & $\mathrm{LC}$ & & II & IV & \\
\hline Euphydryas aurinia & $\mathrm{LC}$ & & II & II & \\
\hline Phengaris arion & LC & & II & IV & \\
\hline Melanargia arge & LC & & II & II/IV & \\
\hline Papilio alexanor & $\mathrm{LC}$ & & II & IV & \\
\hline Papilio hospiton & LC & II & & II/IV & A \\
\hline Parnassius apollo & $\mathrm{LC}$ & II & II & IV & A \\
\hline Parnassius mnemosyne & $\mathrm{LC}$ & & II & IV & \\
\hline Pseudophilotes bavius & LC & & & II/IV & \\
\hline Zerynthia polyxena & $\mathrm{LC}$ & & II & IV & \\
\hline
\end{tabular}

(a) Ratified by all Mediterranean States. Appendix I lists species threatened with extinction, with trade permitted only in exceptional circumstances, Appendix II lists species that are not necessarily now threatened with extinction but that may become so unless trade is closely controlled.

(b) Ratified by all Mediterranean States in the study, except Algeria, Egypt, Israel, and Lebanon. Appendix II - Strictly protected fauna species. Appendix III - Protected fauna species.

(c) Council Directive 92/43/EEC. Must be implemented in all European States of the Mediterranean, Annex II lists species requiring designation of Special Areas of Conservation; Annex IV lists species in need of strict protection.

(d) Must be implemented in all European States of the Mediterranean according to Regulation (EC) No 338/97, Annex B.

maintain or restore to favourable conservation status in their natural range, habitats and species of wild flora and fauna of Community interest and listed in Annexes to the Directive (Council of Europe 2016).

\section{Habitats Directive}

The Habitats Directive ensures the conservation of a wide range of rare, threatened or endemic animal and plant species. Some 200 rare and characteristic habitat types are also targeted for conservation in their own right. The Habitats Directive is also known as Council Directive 92/43/EEC on the Conservation of natural habitats and of wild fauna and flora. It is a European Union directive adopted in 1992 as an EU response to the Bern Convention. It is one of the EU's two directives related to wildlife and nature conservation, the other being the Birds Directive (http://ec.europa.eu/environment/nature/legislation/ habitatsdirective/index_en.htm).

\section{EU regulation on the trade in wild fauna and flora species}

CITES is implemented in the EU through a set of Regulations known as the EU Wildlife Trade Regulations. Currently these are Council Regulation (EC) No 338/97 on the protection of species of wild fauna and flora which deals with the protection of species of wild fauna and flora by regulating trade therein. It lays down the provisions for import, export and re-export as well as internal EU trade in specimens of species listed in its four Annexes (http://ec.europa.eu/environment/cites/ legislation_en.htm).

\subsection{The butterfly monitoring network}

Butterfly Monitoring involves counting butterflies following a standard protocol, often by volunteers. Since its start in 1976, 
butterfly monitoring has expanded into many European countries. At present there are 22 countries where butterflies are monitored. However, most of them are not situated in the Mediterranean region, with the exception of Spain and France. Part of the Spanish network is active in Sierra Nevada, where two of the threatened butterfly species in the Mediterranean can be found (http://www.bc-europe.eu/index.php?id=339).

\subsection{Key Biodiversity Areas for butterflies}

Over the last decade, international conservation organisations have devoted much effort to locate broad scale global priorities for conservation. These include the Endemic Bird Areas (EBAs) (Stattersfield et al. 1998), the Global 200 Ecoregions (Olson et al. 2002), and the Biodiversity Hotspots (Mittermeier et al. 2004), amongst others. Important as they are for informing the investment of globally flexible conservation resources, these large-scale analyses do not address a practical problem. They do not exactly define which sites should be protected at a fine scale. Furthermore, by virtue of their broad scale, some sites which are globally important for biodiversity would not be captured.

Several projects have recently been developed to extend the Important Biodiversity Areas approach to other taxa. These include Important Plant Areas (IPAs), Prime Butterfly Areas, Important Mammal Areas, Prime Dragonfly Areas and Important Sites for Freshwater Biodiversity, with prototype criteria developed for freshwater fish, molluscs, odonates, and crabs. The IUCN Key Biodiversity Areas (KBAs) framework builds on these initiatives and considers all taxonomic groups for which data exist in site identification. KBAs have already been identified in many countries around the world. These can therefore be used as a starting point for national and regional level gap analyses and conservation action.

van Swaay and Warren (2003) developed the European Prime Butterfly Areas, the most important areas for butterfly conservation. However the work was restricted to Europe and a few locations in Turkey and was mainly focused on the species of the Habitats Directive, which means that it did not include all the threatened species according to the IUCN Red List. Therefore it falls short of identifying priority areas for threatened species, especially in the Mediterranean.

Doğa was one of the first organizations to apply the KBA methodology at the national level, in Turkey, in 2006. This work has resulted in a two-volume inventory of Key Biodiversity Areas of Turkey, identifying 305 KBAs, which cover 20,280,149 hectares, equivalent to $26 \%$ of Turkey's surface area. Among these sites, 292 fulfil the KBA criteria for one or more taxonomic groups on a global scale. Thirteen sites are important at a regional scale. Seventeen of Turkey's KBAs have been selected based on the conservation of butterflies. http://www.dogadernegi.org/ en/turkeys-kbas/
A conservation strategy for butterflies has been published for Turkey, including the Mediterranean part of the country (Karaçetin et al. 2011).

\subsection{Strategic planning for Mediterranean species conservation: action plans for butterfly species in Sierra Nevada, Spain}

The Mediterranean hosts an important number of endemic butterflies. Many of these species are now restricted to small areas with low population numbers, some of them highly dependent on low-intensity farming. Climate change alone, or in combination with land abandonment will have a profound effect on these butterflies and increase their risk of extinction. A successful conservation strategy for these species requires three elements:

(1) accurate information on the distribution and population size of these species;

(2) a monitoring programme for species with a relict distribution or population size to identify trends more accurately;

(3) research into the ecology and threats of the species to enable targeted conservation actions to ensure their long term survival,

(4) commitment of the key stakeholders and the implementation of the solutions available.

These are the corner stones of a Species Recovery Program promoted by Butterfly Conservation (http://www.bceurope.eu/). The first phase of this strategy focuses on the four Mediterranean endemics found in Spain (Euchloe bazae, Polyommatus golgus, Polyommatus violetae and Plebejus zullichi). The main project outcome is an Endemic Species Recovery Programme, describing in the plans the possibilities for the long-term survival of these four threatened endemic butterflies.

\subsubsection{The Zullich's Blue}

The main observed threats Plebejus zullichi is facing are urban development related to a ski resort and roads crossing the very limited species habitat, overgrazing, and trampling caused by livestock grazing and by tourists walking outside footpaths or roads. The small extension of the habitat of the species (61 hectares) and its fragmentation (habitat is divided into 39 patches), makes the species particularly sensitive to any threat that limits or damages the unique habitat in which it lives.

Climate change is the main threat for the species in the long term, because the climatic range of the species could be displaced toward higher areas where habitat availability is lower. A considerable percentage of the populations inhabit peaks or tops of ridges and these populations are more vulnerable to the changes caused by climate change. 


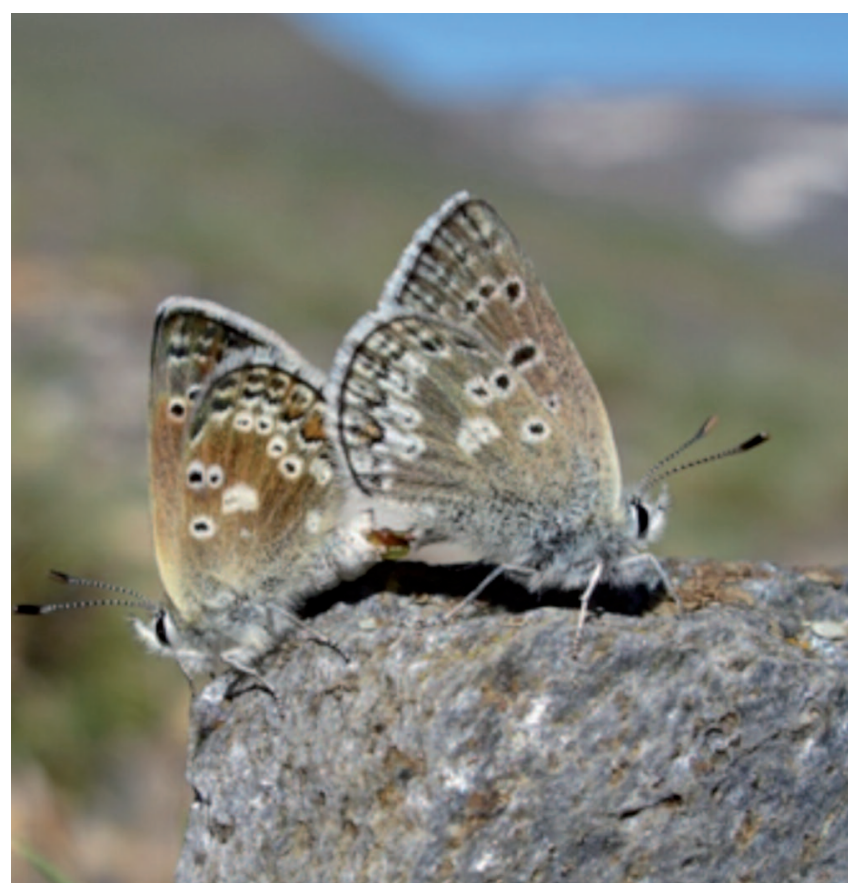

The Zullich's Blue (Plebejus zullichi) is a small butterfly with an extremely restricted range in the high parts of Sierra Nevada. Here its main threat comes from the construction of infrastructure for ski tourism. In the long run the species might be threatened by climate change. (C) Jose Miguel Barea.

The species is legally protected in the Andalusia region and all its populations are within the National and Natural Parks of Sierra Nevada.

Actions for the conservation of the species include: prevent overgrazing with exclusion fences in the most vulnerable populations; avoid trampling by footpath management and information to National and Natural Park visitors; stop new developments and reduce the negative effects of the ski infrastructure and trails; reinforcement of adult and larval food plant populations to mitigate the effects of climate change; and monitor the populations of the butterfly at the larval and adult stage. Other actions comprise captive breeding of the butterfly for population reinforcement and public awareness campaigns including information materials, panels, and media releases with information about the species.

\subsubsection{The Sierra Nevada Blue}

The main threats detected for Polyommatus golgus are, in order of importance: overgrazing, trampling, low densities of its food plant, drought, and development of ski resorts and roads. The habitat of this high altitude species is not dependent on management. Light grazing does not impact upon habitat quality, but whenever grazing becomes heavier it can seriously damage the habitat of the species.

The impact of climate change on the habitat is the main problem the species is already facing. Some of the observed consequences

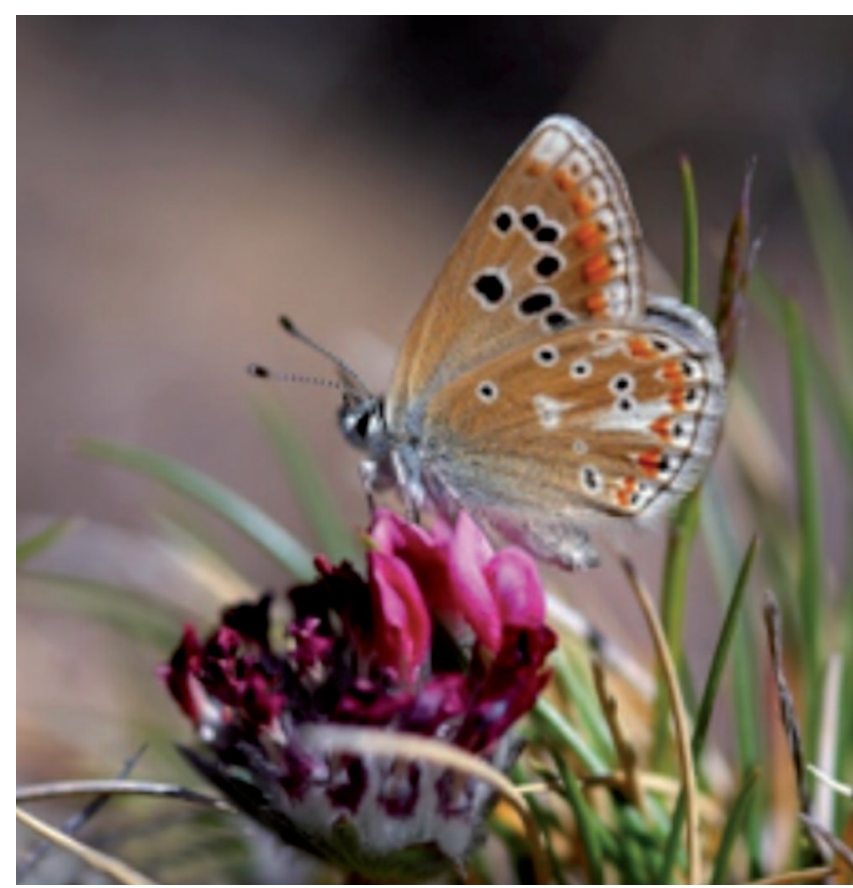

The Nevada Blue (Polyommatus golgus) is restricted to two mountain chains in southern Spain. It is threatened by tourism development and classified as Vulnerable. (อJavier Olivares.

of this change are drought, increased temperatures and the reduction of snow coverage. If these impacts continue, the range of the species would be displaced to higher areas where the habitat might not be suitable. Some populations that live in the highest areas of the mountains are already limited to very small areas with a suitable climate, and climate change would mean their extinction. For all the other populations, the impact of climate change would mean a substantial reduction of the area they occupy.

The species is protected at an international, national and regional level and all its populations live inside protected areas belonging to the European Natura 2000 Network, including one National Park, three Natural Parks and a site protected under the EC Habitats Directive.

Actions planned for the recovery of the species include: build exclusion fences in Sierra Nevada to reduce the effect of grazing upon butterfly populations; restoration of traditional footpaths and closure of shortcuts to prevent trampling; avoid new developments of tourism infrastructure in the area of the actual ski resort or in the neighbouring valleys and restoring damaged habitats; mitigate the effects of climate change through the reinforcement of adult and larval food plant populations (Anthyllis vulneraria); research on the genetics, population trends and the possibility of captive breeding; and raise public awareness using information leaflets and panels in the main areas where the species lives. 


\section{Chapter 5. Conclusions and Recommendations}

This report presents the first comprehensive regional IUCN Red List assessment of the entire butterfly fauna of the Mediterranean region (463 species). Nineteen (4.4\%) out of 428 species evaluated were considered to be threatened (0.5\% being Critically Endangered, 3\% Endangered, and 0.9\% Vulnerable). Due to insufficient knowledge and information, $6.5 \%$ of the assessed species are listed as being Data Deficient in the Mediterranean region. Despite the current lack of data, this group may include some threatened species; increased funding and research attention needs to be directed towards these species. Although limited data availability is often cited as a problem, it should not, however, be used to justify the lack of management.

Overall changes in agricultural practices (intensification, overgrazing, as well as farming abandonment) and urban and infrastructure development are considered to be the biggest threat to butterflies in the Mediterranean region, in one way or another potentially affecting most or possibly almost all of the species present there.

Butterflies provide a wide range of environmental benefits, including pollination and natural pest control. They are an important element of the food chain and prey for birds, bats and other insectivorous animals. Even more, butterflies support a range of other predators and parasites, many of which are specific to individual species, or groups of species. Many species have developed their own suite of chemicals to deter predators and parasites, find a mate, and overcome the chemical defences of their host plant. Each of these chemicals has a potential value and could be exploited economically. For example, powerful antibiotics have been found in the Meadow Brown (Maniola jurtina), one common and widespread species.

To improve the conservation status of Mediterranean butterflies urgent conservation measures are needed. In particular:

- National and international legislation should be fully implemented and revised to include the threatened species identified in this assessment.

- Prioritize field work and data collection for Data Deficient species to determine whether they need conservation actions.

- Species/habitat action plans should be drawn for the most threatened species.

- Butterfly monitoring should be started up in many more parts of the Mediterranean. Only regular counts provide data to follow populations of butterflies in detail.

- Ensure that the strong regional cooperation between experts continues, and start new cooperation efforts with experts from countries where information is scarce, so that the work carried out to produce the first evaluation of the conservation status of native Mediterranean butterflies can be updated as new information becomes available. 


\section{References}

Council of Europe. 2016. Presentation of the Bern Convention. Retrieved from http://www.coe.int/en/web/conventions/full-list/-/conventions/ treaty/104.

Cuttelod, A., García, N., Abdul Malak, D., Temple, H. and Katariya, V. 2008. The Mediterranean: a biodiversity hotspot under threat. In: J.C. Vié, C. Hilton-Taylor and S. N. Stuart (eds.). The 2008 Review of The IUCN Red List of Threatened Species. IUCN Gland, Switzerland.

Devictor, V., van Swaay, C., Brereton, T., et al. 2012. Differences in the climate debts of birds and butterflies at a continental scale. Nature Climate Change 2: 121-124.

Eitschberger, U. and Tamer, P.S. 1990. Cacyreus marshalli Butler, 1898, eine neue Tagfalterart für sie europäische Fauna? (Lepidoptera, Lycaenidae). Atalanta, 21: 101-108.

IUCN. 2011. Guidelines for appropriate uses of IUCN Red List Data. Incorporating the Guidelines for Reporting on Proportion Threatened and the Guidelines on Scientific Collecting of Threatened Species. Version 2. Adopted by the IUCN Red List Committee and IUCN SSC Steering Committee. Downloadable from: http://intranet. iucn.org/webfiles/doc/SpeciesProg/RL_Guidelines_Data_Use.pdf or http://www.iucnredlist.org/documents/RL_Guidelines_Data_Use.pdf

IUCN. 2012a. IUCN Red List Categories and Criteria: Version 3.1. Second edition. Gland, Switzerland and Cambridge, UK: IUCN. iv + 32 pp.

IUCN. 2012b. Guidelines for Application of IUCN Red List Criteria at Regional and National Levels: Version 4.0. Gland, Switzerland and Cambridge, UK: IUCN. iii +41 pp.

IUCN. 2003. Guidelines for Application of IUCN Red List Criteria at Regional Levels: Version 3.0. IUCN Species Survival Commission. IUCN, Gland, Switzerland and Cambridge, UK.

Karaçetin, E., Welch, H.J., Turak, A. Balkiz, Ö. and Welch, G. 2011. Türkiye'deki Kelebeklerin Koruma Stratejisi. Doga Koruma Merkezi, Ankara, Turkey.
Mittermeier, R.A., Robles-Gil, P., Hoffmann, M., Pilgrim, J.D., Brooks, T.B., Mittermeier, C.G., Lamoreux, J.L. and Fonseca, G.A.B. 2004. Hotspots revisited: earth's biologically richest and most endangered ecoregions. CEMEX, Mexico City, Mexico, 390 pp.

Myers, N., Mittermeier, R.A., Mittermeier, C.G., da Fonseca, G.A.B. and Kent, J. 2000. Biodiversity hotspots for conservation priorities. Nature 403: 853-858.

Olson, D.M. and Dinerstein, E. 2002. The Global 200: Priority ecoregions for global conservation. Annals of the Missouri Botanical Garden 89(2): 199-224.

Soyhan, T., Baser, S. and Nazari, V. 2013. First record of Cacyreus marshalli Butler, 1898 (Lycaenidae) from Turkey. Nota lepidopterologica 36(2): 189-190.

Stattersfield, A.J., Crosby, M.J., Long, A.J. and Wege, D.C. 1998. Endemic Bird Areas of the World. Priorities for biodiversity conservation. BirdLife Conservation Series 7. BirdLife International, Cambridge.

Sundseth, K. 2009. Natura 2000 in the Mediterranean Region. Luxembourg, Directorate General for the Environment (European Commission).

Thomas, J.A. and Clarke, R.T. 2004. Extinction rates and butterflies. Science 325: 80-83.

Tshikolovets, V.V. 2011. Butterflies of Europe \& the Mediterranean area. Tshikolovets Publications, Pardubice, Czech Republic, 544 pp.

van Swaay, C. and Warren, M.S. (eds.) 2003. Prime Butterfly Areas in Europe: priority sites for conservation. National Reference Centre for Agriculture, Nature and Fisheries, Ministry of Agriculture, Nature Management and Fisheries, The Netherlands.

van Swaay, C., Cuttelod, A., Collins, S., Maes, D., López Munguira, M. Šašić, M., Settele, J., Verovnik, R., Verstrael, T., Warren, M., Wiemers, M. and Wynhof, I. 2010. European Red List of Butterflies. Luxembourg: Publications Office of the European Union.

Wilson, R.J., Gutiérrez, D., Gutiérrez, J. and Monserrat, V.J. 2007. An elevational shift in butterfly species richness and composition accompanying recent climate change. Global Change Biology 13: 18731887. 


\section{Appendix 1. Summary of regional IUCN Red List status of all Mediterranean butterfly species assessed}

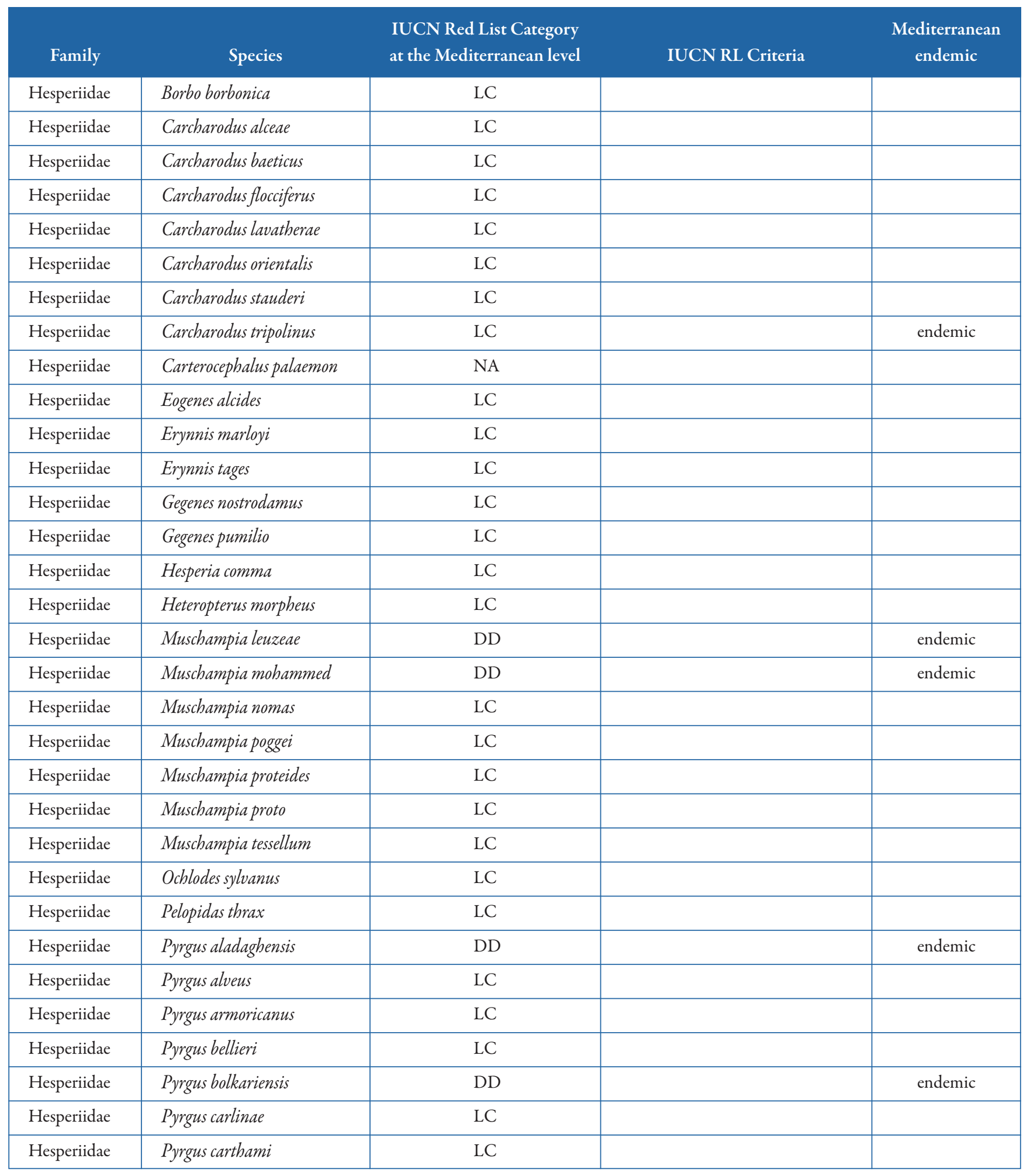


Appendix 1. cont'd, Summary of regional IUCN Red List status of all Mediterranean butterfly species assessed

\begin{tabular}{|c|c|c|c|c|}
\hline Family & Species & $\begin{array}{l}\text { IUCN Red List Category } \\
\text { at the Mediterranean level }\end{array}$ & IUCN RL Criteria & $\begin{array}{l}\text { Mediterranean } \\
\text { endemic }\end{array}$ \\
\hline Hesperiidae & Pyrgus cinarae & LC & & \\
\hline Hesperiidae & Pyrgus cirsii & LC & & \\
\hline Hesperiidae & Pyrgus malvae & LC & & \\
\hline Hesperiidae & Pyrgus malvoides & LC & & \\
\hline Hesperiidae & Pyrgus melotis & LC & & \\
\hline Hesperiidae & Pyrgus onopordi & LC & & \\
\hline Hesperiidae & Pyrgus serratulae & LC & & \\
\hline Hesperiidae & Pyrgus sidae & LC & & \\
\hline Hesperiidae & Spialia doris & LC & & \\
\hline Hesperiidae & Spialia orbifer & LC & & \\
\hline Hesperiidae & Spialia osthelderi & $\mathrm{EN}$ & B2ab(iii) & \\
\hline Hesperiidae & Spialiaphlomidis & $\mathrm{LC}$ & & \\
\hline Hesperiidae & Spialia sertorius & LC & & \\
\hline Hesperiidae & Spialia therapne & LC & & endemic \\
\hline Hesperiidae & Thymelicus acteon & LC & & \\
\hline Hesperiidae & Thymelicus hamza & LC & & endemic \\
\hline Hesperiidae & Thymelicus hyrax & LC & & \\
\hline Hesperiidae & Thymelicus lineola & $\mathrm{LC}$ & & \\
\hline Hesperiidae & Thymelicus novus & NA & & \\
\hline Hesperiidae & Thymelicus sylvestris & LC & & \\
\hline Lycaenidae & Apharitis acamas & NA & & \\
\hline Lycaenidae & Apharitis allardi & LC & & endemic \\
\hline Lycaenidae & Apharitis cilissa & $\mathrm{EN}$ & $\mathrm{B} 2 \mathrm{ab}(\mathrm{iii}, \mathrm{v})$ & \\
\hline Lycaenidae & Apharitis maxima & LC & & \\
\hline Lycaenidae & Apharitis myrmecophila & NA & & \\
\hline Lycaenidae & Apharitis siphax & LC & & endemic \\
\hline Lycaenidae & Apharitis zohra & $\mathrm{DD}$ & & endemic \\
\hline Lycaenidae & Aricia agestis & LC & & \\
\hline Lycaenidae & Aricia anteros & LC & & \\
\hline Lycaenidae & Aricia artaxerxes & LC & & \\
\hline Lycaenidae & Aricia bassoni & $\mathrm{DD}$ & & endemic \\
\hline Lycaenidae & Aricia cramera & LC & & \\
\hline Lycaenidae & Aricia crassipuncta & LC & & \\
\hline Lycaenidae & Aricia eumedon & $\mathrm{LC}$ & & \\
\hline Lycaenidae & Aricia byacinthus & NT & & \\
\hline Lycaenidae & Aricia isaurica & LC & & \\
\hline Lycaenidae & Aricia morronensis & LC & & \\
\hline Lycaenidae & Azanus jesous & LC & & \\
\hline Lycaenidae & Azanus ubaldus & NA & & \\
\hline Lycaenidae & Cacyreus marshalli & NA & & \\
\hline
\end{tabular}


Appendix 1. cont'd, Summary of regional IUCN Red List status of all Mediterranean butterfly species assessed

\begin{tabular}{|c|c|c|c|c|}
\hline Family & Species & $\begin{array}{l}\text { IUCN Red List Category } \\
\text { at the Mediterranean level }\end{array}$ & IUCN RL Criteria & $\begin{array}{l}\text { Mediterranean } \\
\text { endemic }\end{array}$ \\
\hline Lycaenidae & Callophrys avis & LC & & \\
\hline Lycaenidae & Callophrys paulae & $\mathrm{LC}$ & & \\
\hline Lycaenidae & Callophrys rubi & LC & & \\
\hline Lycaenidae & Celastrina argiolus & $\mathrm{LC}$ & & \\
\hline Lycaenidae & Chilades galba & LC & & \\
\hline Lycaenidae & Chilades trochylus & LC & & \\
\hline Lycaenidae & Cupido alcetas & LC & & \\
\hline Lycaenidae & Cupido argiades & $\mathrm{LC}$ & & \\
\hline Lycaenidae & Cupido decoloratus & LC & & \\
\hline Lycaenidae & Cupido lorquinii & LC & & endemic \\
\hline Lycaenidae & Cupido minimus & LC & & \\
\hline Lycaenidae & Cupido osiris & $\mathrm{LC}$ & & \\
\hline Lycaenidae & Cyaniris semiargus & LC & & \\
\hline Lycaenidae & Deudorix livia & LC & & \\
\hline Lycaenidae & Favonius quercus & LC & & \\
\hline Lycaenidae & Glaucopsyche alexis & LC & & \\
\hline Lycaenidae & Glaucopsyche astraea & LC & & \\
\hline Lycaenidae & Glaucopsyche melanops & LC & & \\
\hline Lycaenidae & Glaucopsyche paphos & LC & & endemic \\
\hline Lycaenidae & Iolana iolas & $\mathrm{LC}$ & & \\
\hline Lycaenidae & Laeosopis roboris & $\mathrm{LC}$ & & \\
\hline Lycaenidae & Lampides boeticus & LC & & \\
\hline Lycaenidae & Leptotes pirithous & $\mathrm{LC}$ & & \\
\hline Lycaenidae & Lycaena alciphron & LC & & \\
\hline Lycaenidae & Lycaena asabinus & LC & & \\
\hline Lycaenidae & Lycaena bleusei & LC & & endemic \\
\hline Lycaenidae & Lycaena dispar & NA & & \\
\hline Lycaenidae & Lycaena ochimus & LC & & \\
\hline Lycaenidae & Lycaena ottomana & $\mathrm{LC}$ & & \\
\hline Lycaenidae & Lycaena phlaeas & $\mathrm{LC}$ & & \\
\hline Lycaenidae & Lycaena phoebus & $\mathrm{LC}$ & & \\
\hline Lycaenidae & Lycaena thersamon & $\mathrm{LC}$ & & \\
\hline Lycaenidae & Lycaena thetis & $\mathrm{LC}$ & & \\
\hline Lycaenidae & Lycaena tityrus & $\mathrm{LC}$ & & \\
\hline Lycaenidae & Lycaena virgaureae & $\mathrm{LC}$ & & \\
\hline Lycaenidae & Phengaris alcon & LC & & \\
\hline Lycaenidae & Phengaris arion & $\mathrm{LC}$ & & \\
\hline Lycaenidae & Phengaris nausithous & NA & & \\
\hline Lycaenidae & Phengaris teleius & NA & & \\
\hline Lycaenidae & Plebejus alcedo & LC & & \\
\hline
\end{tabular}


Appendix 1. cont'd, Summary of regional IUCN Red List status of all Mediterranean butterfly species assessed

\begin{tabular}{|c|c|c|c|c|}
\hline Family & Species & $\begin{array}{l}\text { IUCN Red List Category } \\
\text { at the Mediterranean level }\end{array}$ & IUCN RL Criteria & $\begin{array}{l}\text { Mediterranean } \\
\text { endemic }\end{array}$ \\
\hline Lycaenidae & Plebejus allardii & LC & & endemic \\
\hline Lycaenidae & Plebejus argus & LC & & \\
\hline Lycaenidae & Plebejus argyrognomon & LC & & \\
\hline Lycaenidae & Plebejus bellieri & LC & & \\
\hline Lycaenidae & Plebejus eurypilus & LC & & \\
\hline Lycaenidae & Plebejus hespericus & LC & & endemic \\
\hline Lycaenidae & Plebejusidas & LC & & \\
\hline Lycaenidae & Plebejus loewii & LC & & \\
\hline Lycaenidae & Plebejus martini & $\mathrm{DD}$ & & endemic \\
\hline Lycaenidae & Plebejuspbilbyi & LC & & \\
\hline Lycaenidae & Plebejuspsyloritus & LC & & endemic \\
\hline Lycaenidae & Plebejuspylaon & LC & & \\
\hline Lycaenidae & Plebejus vogelii & EN & B2ab (ii, iii, v) & endemic \\
\hline Lycaenidae & Plebejus zullichi & $\mathrm{EN}$ & B2ac(iv) & endemic \\
\hline Lycaenidae & Polyommatus actis & $\mathrm{DD}$ & & \\
\hline Lycaenidae & Polyommatus admetus & LC & & \\
\hline Lycaenidae & Polyommatus albicans & LC & & \\
\hline Lycaenidae & Polyommatus alcestis & $\mathrm{LC}$ & & \\
\hline Lycaenidae & Polyommatus amandus & $\mathrm{LC}$ & & \\
\hline Lycaenidae & Polyommatus aroaniensis & LC & & endemic \\
\hline Lycaenidae & Polyommatus atlanticus & NT & & endemic \\
\hline Lycaenidae & Polyommatus bellargus & LC & & \\
\hline Lycaenidae & Polyommatus bollandi & $\mathrm{CR}$ & B1ab(iii) B2ab(iii) & endemic \\
\hline Lycaenidae & Polyommatus caelestissimus & LC & & endemic \\
\hline Lycaenidae & Polyommatus carmon & LC & & \\
\hline Lycaenidae & Polyommatus celina & LC & & \\
\hline Lycaenidae & Polyommatus cilicius & $\mathrm{DD}$ & & endemic \\
\hline Lycaenidae & Polyommatus coelestinus & LC & & \\
\hline Lycaenidae & Polyommatus coridon & LC & & \\
\hline Lycaenidae & Polyommatus cornelia & LC & & \\
\hline Lycaenidae & Polyommatus dama & $\mathrm{CR}$ & $(\mathrm{i}, \mathrm{ii}, \mathrm{iii}, \mathrm{v})+2 \mathrm{ab}(\mathrm{i}, \mathrm{ii}$, & \\
\hline Lycaenidae & Polyommatus damon & LC & & \\
\hline Lycaenidae & Polyommatus daphnis & LC & & \\
\hline Lycaenidae & Polyommatus dolus & $\mathrm{LC}$ & & endemic \\
\hline Lycaenidae & Polyommatus dorylas & LC & & \\
\hline Lycaenidae & Polyommatus ellisoni & $\mathrm{DD}$ & & endemic \\
\hline Lycaenidae & Polyommatus eros & LC & & \\
\hline Lycaenidae & Polyommatus escheri & $\mathrm{LC}$ & & \\
\hline Lycaenidae & Polyommatusfabressei & LC & & endemic \\
\hline Lycaenidae & Polyommatus fulgens & LC & & \\
\hline
\end{tabular}


Appendix 1. cont'd, Summary of regional IUCN Red List status of all Mediterranean butterfly species assessed

\begin{tabular}{|c|c|c|c|c|}
\hline Family & Species & $\begin{array}{l}\text { IUCN Red List Category } \\
\text { at the Mediterranean level }\end{array}$ & IUCN RL Criteria & $\begin{array}{c}\text { Mediterranean } \\
\text { endemic }\end{array}$ \\
\hline Lycaenidae & Polyommatus golgus & $\mathrm{VU}$ & D2 & endemic \\
\hline Lycaenidae & Polyommatus guezelmavi & NT & & endemic \\
\hline Lycaenidae & Polyommatus hispanus & LC & & \\
\hline Lycaenidae & Polyommatus hopfferi & $\mathrm{LC}$ & & \\
\hline Lycaenidae & Polyommatusicarus & LC & & \\
\hline Lycaenidae & Polyommatus iphicarmon & VU & D2 & endemic \\
\hline Lycaenidae & Polyommatus iphigenia & LC & & \\
\hline Lycaenidae & Polyommatus isauricoides & $\mathrm{DD}$ & & endemic \\
\hline Lycaenidae & Polyommatus larseni & $\mathrm{DD}$ & & endemic \\
\hline Lycaenidae & Polyommatus lycius & $\mathrm{VU}$ & D1 & endemic \\
\hline Lycaenidae & Polyommatus menalcas & $\mathrm{LC}$ & & \\
\hline Lycaenidae & Polyommatus mithridates & $\mathrm{DD}$ & & \\
\hline Lycaenidae & Polyommatus myrrha & LC & & \\
\hline Lycaenidae & Polyommatus nivescens & LC & & \\
\hline Lycaenidae & Polyommatus ossmar & LC & & \\
\hline Lycaenidae & Polyommatus phyllis & LC & & \\
\hline Lycaenidae & Polyommatus poseidon & $\mathrm{LC}$ & & \\
\hline Lycaenidae & Polyommatus punctiferus & LC & & endemic \\
\hline Lycaenidae & Polyommatus ripartii & LC & & \\
\hline Lycaenidae & Polyommatus schuriani & $\mathrm{DD}$ & & \\
\hline Lycaenidae & Polyommatus sertavulensis & $\mathrm{DD}$ & & endemic \\
\hline Lycaenidae & Polyommatus sigberti & $\mathrm{DD}$ & & \\
\hline Lycaenidae & Polyommatus syriacus & $\mathrm{DD}$ & & endemic \\
\hline Lycaenidae & Polyommatus theresiae & $\mathrm{EN}$ & B1ab(iii, v) B2ab(iii, v) & endemic \\
\hline Lycaenidae & Polyommatus thersites & $\mathrm{LC}$ & & \\
\hline Lycaenidae & Polyommatus violetae & $\mathrm{LC}$ & & endemic \\
\hline Lycaenidae & Polyommatus wagneri & $\mathrm{DD}$ & & \\
\hline Lycaenidae & Pseudophilotes abencerragus & LC & & \\
\hline Lycaenidae & Pseudophilotes barbagiae & $\mathrm{DD}$ & & endemic \\
\hline Lycaenidae & Pseudophilotes baton & $\mathrm{LC}$ & & \\
\hline Lycaenidae & Pseudophilotes bavius & $\mathrm{LC}$ & & \\
\hline Lycaenidae & Pseudophilotes fatma & EN & B2ab(iii, v) & endemic \\
\hline Lycaenidae & Pseudophilotes jordanicus & $\mathrm{DD}$ & & endemic \\
\hline Lycaenidae & Pseudophilotes panoptes & NT & & endemic \\
\hline Lycaenidae & Pseudophilotes vicrama & $\mathrm{LC}$ & & \\
\hline Lycaenidae & Satyrium abdominalis & LC & & \\
\hline Lycaenidae & Satyrium acaciae & $\mathrm{LC}$ & & \\
\hline Lycaenidae & Satyrium esculi & $\mathrm{LC}$ & & \\
\hline Lycaenidae & Satyrium ilicis & LC & & \\
\hline Lycaenidae & Satyrium ledereri & NT & & \\
\hline
\end{tabular}


Appendix 1. cont'd, Summary of regional IUCN Red List status of all Mediterranean butterfly species assessed

\begin{tabular}{|c|c|c|c|c|}
\hline Family & Species & $\begin{array}{l}\text { IUCN Red List Category } \\
\text { at the Mediterranean level }\end{array}$ & IUCN RL Criteria & $\begin{array}{l}\text { Mediterranean } \\
\text { endemic }\end{array}$ \\
\hline Lycaenidae & Satyrium myrtale & NA & & \\
\hline Lycaenidae & Satyrium pruni & $\mathrm{LC}$ & & \\
\hline Lycaenidae & Satyrium spini & $\mathrm{LC}$ & & \\
\hline Lycaenidae & Satyrium w-album & $\mathrm{LC}$ & & \\
\hline Lycaenidae & Satyrium zabni & $\mathrm{LC}$ & & \\
\hline Lycaenidae & Scolitantides orion & $\mathrm{LC}$ & & \\
\hline Lycaenidae & Tarucus balkanicus & $\mathrm{LC}$ & & \\
\hline Lycaenidae & Tarucus rosaceus & LC & & \\
\hline Lycaenidae & Tarucus theophrastus & $\mathrm{LC}$ & & \\
\hline Lycaenidae & Thecla betulae & $\mathrm{LC}$ & & \\
\hline Lycaenidae & Tomares ballus & $\mathrm{LC}$ & & \\
\hline Lycaenidae & Tomares mauretanicus & $\mathrm{LC}$ & & endemic \\
\hline Lycaenidae & Tomares nesimachus & $\mathrm{LC}$ & & \\
\hline Lycaenidae & Tomares nogelii & $\mathrm{LC}$ & & \\
\hline Lycaenidae & Turanana endymion & $\mathrm{LC}$ & & \\
\hline Lycaenidae & Turanana taygetica & NT & & endemic \\
\hline Lycaenidae & Zizeeria karsandra & LC & & \\
\hline Lycaenidae & Zizeeria knysna & $\mathrm{LC}$ & & \\
\hline Nymphalidae & Aglais io & LC & & \\
\hline Nymphalidae & Aglais urticae & $\mathrm{LC}$ & & \\
\hline Nymphalidae & Apatura ilia & $\mathrm{LC}$ & & \\
\hline Nymphalidae & Apatura iris & $\mathrm{LC}$ & & \\
\hline Nymphalidae & Apatura metis & LC & & \\
\hline Nymphalidae & Aphantopus hyperantus & $\mathrm{LC}$ & & \\
\hline Nymphalidae & Araschnia levana & NA & & \\
\hline Nymphalidae & Arethusana aksouali & EN & $\mathrm{A} 2(\mathrm{c}) \mathrm{B} 1 \mathrm{ab}(\mathrm{ii}, \mathrm{v})$ & endemic \\
\hline Nymphalidae & Arethusana arethusa & $\mathrm{LC}$ & & \\
\hline Nymphalidae & Argynnis adippe & $\mathrm{LC}$ & & \\
\hline Nymphalidae & Argynnis aglaja & LC & & \\
\hline Nymphalidae & Argynnis auresiana & $\mathrm{LC}$ & & endemic \\
\hline Nymphalidae & Argynnis elisa & $\mathrm{LC}$ & & endemic \\
\hline Nymphalidae & Argynnis niobe & $\mathrm{LC}$ & & \\
\hline Nymphalidae & Argynnis pandora & $\mathrm{LC}$ & & \\
\hline Nymphalidae & Argynnis paphia & $\mathrm{LC}$ & & \\
\hline Nymphalidae & Berberia abdelkader & LC & & \\
\hline Nymphalidae & Berberia lambessanus & DD & & endemic \\
\hline Nymphalidae & Boloria dia & $\mathrm{LC}$ & & \\
\hline Nymphalidae & Boloria euphrosyne & $\mathrm{LC}$ & & \\
\hline Nymphalidae & Boloria graeca & $\mathrm{LC}$ & & \\
\hline Nymphalidae & Boloria selene & $\mathrm{LC}$ & & \\
\hline
\end{tabular}


Appendix 1. cont'd, Summary of regional IUCN Red List status of all Mediterranean butterfly species assessed

\begin{tabular}{|c|c|c|c|c|}
\hline Family & Species & $\begin{array}{l}\text { IUCN Red List Category } \\
\text { at the Mediterranean level }\end{array}$ & IUCN RL Criteria & $\begin{array}{c}\text { Mediterranean } \\
\text { endemic }\end{array}$ \\
\hline Nymphalidae & Boloria titania & NA & & \\
\hline Nymphalidae & Brenthis daphne & $\mathrm{LC}$ & & \\
\hline Nymphalidae & Brenthis hecate & $\mathrm{LC}$ & & \\
\hline Nymphalidae & Brenthis ino & $\mathrm{LC}$ & & \\
\hline Nymphalidae & Brintesia circe & LC & & \\
\hline Nymphalidae & Charaxes jasius & $\mathrm{LC}$ & & \\
\hline Nymphalidae & Chazara bischoffii & LC & & \\
\hline Nymphalidae & Chazara briseis & $\mathrm{LC}$ & & \\
\hline Nymphalidae & Chazara persephone & LC & & \\
\hline Nymphalidae & Chazara prieuri & LC & & endemic \\
\hline Nymphalidae & Coenonympha arcania & $\mathrm{LC}$ & & \\
\hline Nymphalidae & Coenonympha arcanioides & $\mathrm{LC}$ & & endemic \\
\hline Nymphalidae & Coenonympha corinna & LC & & endemic \\
\hline Nymphalidae & Coenonympha dorus & $\mathrm{LC}$ & & \\
\hline Nymphalidae & Coenonympha fettigii & LC & & endemic \\
\hline Nymphalidae & Coenonympha glycerion & LC & & \\
\hline Nymphalidae & Coenonympha leander & $\mathrm{LC}$ & & \\
\hline Nymphalidae & Coenonympha oedippus & NA & & \\
\hline Nymphalidae & Coenonympha orientalis & LC & & \\
\hline Nymphalidae & Coenonympha pamphilus & LC & & \\
\hline Nymphalidae & Coenonympha rhodopensis & $\mathrm{LC}$ & & \\
\hline Nymphalidae & Coenonympha saadi & LC & & \\
\hline Nymphalidae & Coenonympha thyrsis & $\mathrm{LC}$ & & endemic \\
\hline Nymphalidae & Coenonympha vaucheri & NT & & endemic \\
\hline Nymphalidae & Danaus chrysippus & $\mathrm{LC}$ & & \\
\hline Nymphalidae & Danaus plexippus & $\mathrm{LC}$ & & \\
\hline Nymphalidae & Erebia aethiops & NA & & \\
\hline Nymphalidae & Erebia cassioides & LC & & \\
\hline Nymphalidae & Erebia epiphron & $\mathrm{LC}$ & & \\
\hline Nymphalidae & Erebia epistygne & $\mathrm{LC}$ & & \\
\hline Nymphalidae & Erebia euryale & $\mathrm{LC}$ & & \\
\hline Nymphalidae & Erebia gorge & $\mathrm{LC}$ & & \\
\hline Nymphalidae & Erebia hispania & $\mathrm{LC}$ & & endemic \\
\hline Nymphalidae & Erebia ligea & $\mathrm{NA}$ & & \\
\hline Nymphalidae & Erebia medusa & $\mathrm{LC}$ & & \\
\hline Nymphalidae & Erebia melas & LC & & \\
\hline Nymphalidae & Erebia meolans & $\mathrm{LC}$ & & \\
\hline Nymphalidae & Erebia montana & $\mathrm{LC}$ & & \\
\hline Nymphalidae & Erebia neoridas & LC & & \\
\hline Nymphalidae & Erebia oeme & LC & & \\
\hline
\end{tabular}


Appendix 1. cont'd, Summary of regional IUCN Red List status of all Mediterranean butterfly species assessed

\begin{tabular}{|c|c|c|c|c|}
\hline Family & Species & $\begin{array}{l}\text { IUCN Red List Category } \\
\text { at the Mediterranean level }\end{array}$ & IUCN RL Criteria & $\begin{array}{l}\text { Mediterranean } \\
\text { endemic }\end{array}$ \\
\hline Nymphalidae & Erebia ottomana & LC & & \\
\hline Nymphalidae & Erebiarhodopensis & LC & & \\
\hline Nymphalidae & Erebia scipio & LC & & \\
\hline Nymphalidae & Erebia triaria & LC & & \\
\hline Nymphalidae & Erebia zapateri & LC & & endemic \\
\hline Nymphalidae & Euphydryas aurinia & LC & & \\
\hline Nymphalidae & Euphydryas desfontainii & $\mathrm{LC}$ & & \\
\hline Nymphalidae & Euphydryas maturna & NA & & \\
\hline Nymphalidae & Euphydryas orientalis & $\mathrm{DD}$ & & \\
\hline Nymphalidae & Hipparchia algirica & LC & & endemic \\
\hline Nymphalidae & Hipparchia aristaeus & LC & & endemic \\
\hline Nymphalidae & Hipparchia blachieri & $\mathrm{LC}$ & & endemic \\
\hline Nymphalidae & Hipparchia caroli & LC & & endemic \\
\hline Nymphalidae & Hipparchia christenseni & $\mathrm{EN}$ & $\mathrm{B} 2 \mathrm{ab}(\mathrm{v})$ & endemic \\
\hline Nymphalidae & Hipparchia cretica & LC & & endemic \\
\hline Nymphalidae & Hipparchia cypriensis & LC & & endemic \\
\hline Nymphalidae & Hipparchia ellena & $\mathrm{DD}$ & & endemic \\
\hline Nymphalidae & Hipparchia fagi & $\mathrm{LC}$ & & \\
\hline Nymphalidae & Hipparchia fatua & $\mathrm{LC}$ & & \\
\hline Nymphalidae & Hipparchia fidia & LC & & \\
\hline Nymphalidae & Hipparchia hansii & LC & & endemic \\
\hline Nymphalidae & Hipparchia leighebi & NT & & endemic \\
\hline Nymphalidae & Hipparchia mersina & LC & & endemic \\
\hline Nymphalidae & Hipparchia neomiris & LC & & endemic \\
\hline Nymphalidae & Hipparchia parisatis & LC & & \\
\hline Nymphalidae & Hipparcbia pellucida & LC & & \\
\hline Nymphalidae & Hipparchia pisidice & $\mathrm{LC}$ & & \\
\hline Nymphalidae & Hipparchia powelli & DD & & endemic \\
\hline Nymphalidae & Hipparchia sbordonii & EN & Blac(iv) & endemic \\
\hline Nymphalidae & Hipparchia semele & LC & & \\
\hline Nymphalidae & Hipparchia senthes & LC & & \\
\hline Nymphalidae & Hipparcbia statilinus & LC & & \\
\hline Nymphalidae & Hipparchia syriaca & LC & & \\
\hline Nymphalidae & Hipparchia volgensis & $\mathrm{LC}$ & & \\
\hline Nymphalidae & Hypolimnas misippus & NA & & \\
\hline Nymphalidae & Hyponephele kocaki & $\mathrm{DD}$ & & \\
\hline Nymphalidae & Hyponephele lupina & LC & & \\
\hline Nymphalidae & Hyponephele lycaon & $\mathrm{LC}$ & & \\
\hline Nymphalidae & Hyponephele maroccana & LC & & endemic \\
\hline Nymphalidae & Hyponephele wagneri & LC & & \\
\hline
\end{tabular}


Appendix 1. cont'd, Summary of regional IUCN Red List status of all Mediterranean butterfly species assessed

\begin{tabular}{|c|c|c|c|c|}
\hline Family & Species & $\begin{array}{l}\text { IUCN Red List Category } \\
\text { at the Mediterranean level }\end{array}$ & IUCN RL Criteria & $\begin{array}{l}\text { Mediterranean } \\
\text { endemic }\end{array}$ \\
\hline Nymphalidae & Issoria lathonia & LC & & \\
\hline Nymphalidae & Junonia bierta & NA & & \\
\hline Nymphalidae & Junonia orithya & NA & & \\
\hline Nymphalidae & Kirinia climene & LC & & \\
\hline Nymphalidae & Kirinia roxelana & $\mathrm{LC}$ & & \\
\hline Nymphalidae & Lasiommata maera & LC & & \\
\hline Nymphalidae & Lasiommata meadewaldoi & EN & B2ac(iv) & endemic \\
\hline Nymphalidae & Lasiommata megera & LC & & \\
\hline Nymphalidae & Lasiommata paramegaera & LC & & endemic \\
\hline Nymphalidae & Lasiommata petropolitana & LC & & \\
\hline Nymphalidae & Libythea celtis & LC & & \\
\hline Nymphalidae & Limenitis camilla & $\mathrm{LC}$ & & \\
\hline Nymphalidae & Limenitispopuli & LC & & \\
\hline Nymphalidae & Limenitis reducta & LC & & \\
\hline Nymphalidae & Lopinga achine & NA & & \\
\hline Nymphalidae & Maniola chia & NT & & endemic \\
\hline Nymphalidae & Maniola cypricola & LC & & endemic \\
\hline Nymphalidae & Maniola halicarnassus & $\mathrm{EN}$ & $\mathrm{B} 1 \mathrm{ab}(\mathrm{iii})+2 \mathrm{ab}(\mathrm{iii})$ & endemic \\
\hline Nymphalidae & Maniola jurtina & $\mathrm{LC}$ & & \\
\hline Nymphalidae & Maniola megala & LC & & endemic \\
\hline Nymphalidae & Maniola nurag & LC & & endemic \\
\hline Nymphalidae & Maniola telmessia & LC & & \\
\hline Nymphalidae & Melanargia arge & LC & & endemic \\
\hline Nymphalidae & Melanargia galathea & $\mathrm{LC}$ & & \\
\hline Nymphalidae & Melanargia grumi & LC & & \\
\hline Nymphalidae & Melanargia ines & LC & & \\
\hline Nymphalidae & Melanargia lachesis & $\mathrm{LC}$ & & \\
\hline Nymphalidae & Melanargia larissa & $\mathrm{LC}$ & & \\
\hline Nymphalidae & Melanargia lucasi & LC & & endemic \\
\hline Nymphalidae & Melanargia occitanica & LC & & \\
\hline Nymphalidae & Melanargia pherusa & LC & & endemic \\
\hline Nymphalidae & Melanargia russiae & LC & & \\
\hline Nymphalidae & Melanargia syriaca & LC & & \\
\hline Nymphalidae & Melanargia titea & $\mathrm{LC}$ & & endemic \\
\hline Nymphalidae & Melitaea aetherie & $\mathrm{LC}$ & & endemic \\
\hline Nymphalidae & Melitaea arduinna & LC & & \\
\hline Nymphalidae & Melitaea athalia & LC & & \\
\hline Nymphalidae & Melitaea aurelia & NA & & \\
\hline Nymphalidae & Melitaea britomartis & NA & & \\
\hline Nymphalidae & Melitaea cinxia & LC & & \\
\hline
\end{tabular}


Appendix 1. cont'd, Summary of regional IUCN Red List status of all Mediterranean butterfly species assessed

\begin{tabular}{|c|c|c|c|c|}
\hline Family & Species & $\begin{array}{l}\text { IUCN Red List Category } \\
\text { at the Mediterranean level }\end{array}$ & IUCN RL Criteria & $\begin{array}{l}\text { Mediterranean } \\
\text { endemic }\end{array}$ \\
\hline Nymphalidae & Melitaea collina & LC & & \\
\hline Nymphalidae & Melitaea deione & LC & & \\
\hline Nymphalidae & Melitaea deserticola & LC & & \\
\hline Nymphalidae & Melitaea diamina & LC & & \\
\hline Nymphalidae & Melitaea didyma & LC & & \\
\hline Nymphalidae & Melitaea ornata & LC & & \\
\hline Nymphalidae & Melitaea parthenoides & LC & & \\
\hline Nymphalidae & Melitaea persea & LC & & \\
\hline Nymphalidae & Melitaea phoebe & LC & & \\
\hline Nymphalidae & Melitaea punica & LC & & endemic \\
\hline Nymphalidae & Melitaea trivia & LC & & \\
\hline Nymphalidae & Minois dryas & NA & & \\
\hline Nymphalidae & Neptis rivularis & NA & & \\
\hline Nymphalidae & Neptis sappho & NA & & \\
\hline Nymphalidae & Nymphalis antiopa & LC & & \\
\hline Nymphalidae & Nymphalispolychloros & LC & & \\
\hline Nymphalidae & Nymphalis xanthomelas & NA & & \\
\hline Nymphalidae & Pararge aegeria & $\mathrm{LC}$ & & \\
\hline Nymphalidae & Polygonia c-album & LC & & \\
\hline Nymphalidae & Polygonia egea & LC & & \\
\hline Nymphalidae & Proterebia phegea & LC & & \\
\hline Nymphalidae & Pseudochazara amymone & $\mathrm{EN}$ & B2ab(ii, iii, iv) & endemic \\
\hline Nymphalidae & Pseudochazara anthelea & LC & & \\
\hline Nymphalidae & Pseudochazara atlantis & LC & & endemic \\
\hline Nymphalidae & Pseudochazara beroe & LC & & \\
\hline Nymphalidae & Pseudochazara geyeri & NA & & \\
\hline Nymphalidae & Pseudochazara graeca & $\mathrm{LC}$ & & endemic \\
\hline Nymphalidae & Pseudochazara mamurra & LC & & \\
\hline Nymphalidae & Pseudochazara mniszechii & LC & & \\
\hline Nymphalidae & Pseudochazara orestes & NA & & \\
\hline Nymphalidae & Pseudochazara pelopea & LC & & \\
\hline Nymphalidae & Pseudochazara thelephassa & LC & & \\
\hline Nymphalidae & Pseudochazara williamsi & LC & & endemic \\
\hline Nymphalidae & Pyronia bathseba & $\mathrm{LC}$ & & \\
\hline Nymphalidae & Pyronia cecilia & LC & & \\
\hline Nymphalidae & Pyronia janiroides & $\mathrm{DD}$ & & endemic \\
\hline Nymphalidae & Pyronia tithonus & LC & & \\
\hline Nymphalidae & Satyrus actaea & LC & & \\
\hline Nymphalidae & Satyrus amasinus & LC & & \\
\hline Nymphalidae & Satyrus favonius & LC & & \\
\hline
\end{tabular}


Appendix 1. cont'd, Summary of regional IUCN Red List status of all Mediterranean butterfly species assessed

\begin{tabular}{|c|c|c|c|c|}
\hline Family & Species & $\begin{array}{l}\text { IUCN Red List Category } \\
\text { at the Mediterranean level }\end{array}$ & IUCN RL Criteria & $\begin{array}{l}\text { Mediterranean } \\
\text { endemic }\end{array}$ \\
\hline Nymphalidae & Satyrus ferula & LC & & \\
\hline Nymphalidae & Thaleropsis ionia & LC & & \\
\hline Nymphalidae & Vanessa atalanta & LC & & \\
\hline Nymphalidae & Vanessa cardui & LC & & \\
\hline Nymphalidae & Vanessa virginiensis & $\mathrm{LC}$ & & \\
\hline Nymphalidae & Ypthima asterope & LC & & \\
\hline Papilionidae & Archon apollinus & LC & & \\
\hline Papilionidae & Iphiclidespodalirius & LC & & \\
\hline Papilionidae & Papilio alexanor & LC & & \\
\hline Papilionidae & Papilio demoleus & NA & & \\
\hline Papilionidae & Papilio hospiton & $\mathrm{LC}$ & & endemic \\
\hline Papilionidae & Papilio machaon & $\mathrm{LC}$ & & \\
\hline Papilionidae & Parnassius apollo & LC & & \\
\hline Papilionidae & Parnassius mnemosyne & LC & & \\
\hline Papilionidae & Zerynthia cassandra & LC & & \\
\hline Papilionidae & Zerynthia cerisyi & LC & & \\
\hline Papilionidae & Zerynthia cretica & LC & & endemic \\
\hline Papilionidae & Zerynthia deyrollei & LC & & \\
\hline Papilionidae & Zerynthia polyxena & $\mathrm{LC}$ & & \\
\hline Papilionidae & Zerynthia rumina & LC & & \\
\hline Pieridae & Belenois aurora & NA & & \\
\hline Pieridae & Anthocharis belia & LC & & endemic \\
\hline Pieridae & Anthocharis cardamines & LC & & \\
\hline Pieridae & Anthocharis damone & LC & & \\
\hline Pieridae & Anthocharis euphenoides & LC & & \\
\hline Pieridae & Anthocharis gruneri & LC & & \\
\hline Pieridae & Aporia crataegi & $\mathrm{LC}$ & & \\
\hline Pieridae & Catopsilia florella & NA & & \\
\hline Pieridae & Colias alfacariensis & LC & & \\
\hline Pieridae & Colias aurorina & LC & & \\
\hline Pieridae & Colias caucasica & EN & B12ab(iii, iv) & \\
\hline Pieridae & Colias chlorocoma & $\mathrm{DD}$ & & \\
\hline Pieridae & Colias crocea & LC & & \\
\hline Pieridae & Colias erate & $\mathrm{LC}$ & & \\
\hline Pieridae & Colias hyale & NA & & \\
\hline Pieridae & Colotis chrysonome & NA & & \\
\hline Pieridae & Colotis evagore & LC & & \\
\hline Pieridae & Colotisfausta & LC & & \\
\hline Pieridae & Colotisphisadia & NA & & \\
\hline Pieridae & Euchloe ausonia & LC & & \\
\hline
\end{tabular}


Appendix 1. cont'd, Summary of regional IUCN Red List status of all Mediterranean butterfly species assessed

\begin{tabular}{|c|c|c|c|c|}
\hline Family & Species & $\begin{array}{l}\text { IUCN Red List Category } \\
\text { at the Mediterranean level }\end{array}$ & IUCN RL Criteria & $\begin{array}{l}\text { Mediterranean } \\
\text { endemic }\end{array}$ \\
\hline Pieridae & Euchloe bazae & LC & & endemic \\
\hline Pieridae & Euchloe belemia & LC & & \\
\hline Pieridae & Euchloe charlonia & LC & & \\
\hline Pieridae & Euchloe crameri & LC & & \\
\hline Pieridae & Euchloe falloui & LC & & \\
\hline Pieridae & Euchloe insularis & LC & & endemic \\
\hline Pieridae & Euchloepechi & $\mathrm{DD}$ & & endemic \\
\hline Pieridae & Euchloepenia & LC & & \\
\hline Pieridae & Euchloe tagis & LC & & \\
\hline Pieridae & Gonepteryx cleopatra & LC & & \\
\hline Pieridae & Gonepteryx farinosa & LC & & \\
\hline Pieridae & Gonepteryx rhamni & $\mathrm{LC}$ & & \\
\hline Pieridae & Leptidea duponcheli & LC & & \\
\hline Pieridae & Leptidea juvernica & LC & & \\
\hline Pieridae & Leptidea reali & LC & & endemic \\
\hline Pieridae & Leptidea sinapis & LC & & \\
\hline Pieridae & Pieris brassicae & LC & & \\
\hline Pieridae & Pieris bryoniae & NA & & \\
\hline Pieridae & Pieris ergane & LC & & \\
\hline Pieridae & Pieriskrueperi & LC & & \\
\hline Pieridae & Pieris mannii & LC & & \\
\hline Pieridae & Pieris napi & LC & & \\
\hline Pieridae & Pieris rapae & LC & & \\
\hline Pieridae & Pieris segonzaci & $\mathrm{VU}$ & B2b(iii, v) c(iv) & endemic \\
\hline Pieridae & Pontia callidice & LC & & \\
\hline Pieridae & Pontia chloridice & LC & & \\
\hline Pieridae & Pontia daplidice & $\mathrm{LC}$ & & \\
\hline Pieridae & Pontia edusa & $\mathrm{LC}$ & & \\
\hline Pieridae & Pontia glauconome & LC & & \\
\hline Pieridae & Zegris eupheme & LC & & \\
\hline Riodinidae & Hamearis lucina & LC & & \\
\hline
\end{tabular}





\section{8 C HisT}

THE IUCN RED LIST

OF THREATENED SPECIES*

INTERNATIONAL UNION

FOR CONSERVATION OF NATURE

IUCN Centre for Mediterranean Cooperation

C/ Marie Curie 22

29590 Campanillas

Malaga, Spain

Tel. : +34952028430

Fax : +34 952028145

uicnmed@iucn.org

http://www.iucn.org/mediterranean

http://www.iucn.org/resources/publications

Core support for the IUCN Centre for Mediterranean Cooperation is provided by:
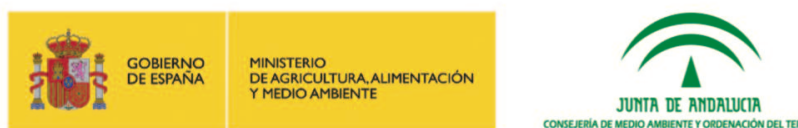